\title{
Modeling the chemical effects of ship exhaust in the cloud-free marine boundary layer
}

\author{
R. von Glasow ${ }^{1,3}$, M. G. Lawrence ${ }^{1}$, R. Sander ${ }^{1}$, and P. J. Crutzen ${ }^{1,2}$ \\ ${ }^{1}$ Max-Planck-Institut für Chemie, Atmospheric Chemistry Division, PO Box 3060, 55020 Mainz, Germany \\ ${ }^{2}$ Center for Atmospheric Sciences, Scripps Institution of Oceanography, University of California at San Diego, La Jolla, CA \\ 92093-0221, USA \\ 3 now at Scripps
}

Received: 19 April 2002 - Published in Atmos. Chem. Phys. Discuss.: 7 June 2002

Revised: 31 January 2003 - Accepted: 3 February 2003 - Published: 21 February 2003

\begin{abstract}
The chemical evolution of the exhaust plumes of ocean-going ships in the cloud-free marine boundary layer is examined with a box model. Dilution of the ship plume via entrainment of background air was treated as in studies of aircraft emissions and was found to be a very important process that significantly alters model results. We estimated the chemical lifetime (defined as the time when differences between plume and background air are reduced to $5 \%$ or less) of the exhaust plume of a single ship to be 2 days. Increased concentrations of $\mathrm{NO}_{\mathrm{x}}\left(=\mathrm{NO}+\mathrm{NO}_{2}\right)$ in the plume air lead to higher catalytical photochemical production rates of $\mathrm{O}_{3}$ and also of $\mathrm{OH}$. Due to increased $\mathrm{OH}$ concentrations in the plume, the lifetime of many species (especially $\mathrm{NO}_{\mathrm{x}}$ ) is significantly reduced in plume air. The chemistry on background aerosols has a significant effect on gas phase chemistry in the ship plume, while partly soluble shipproduced aerosols are computed to only have a very small effect. Soot particles emitted by ships showed no effect on gas phase chemistry. Halogen species that are released from sea salt aerosols are slightly increased in plume air. In the early plume stages, however, the mixing ratio of $\mathrm{BrO}$ is decreased because it reacts rapidly with NO. To study the global effects of ship emissions we used a simple upscaling approach which suggested that the parameterization of ship emissions in global chemistry models as a constant source at the sea surface leads to an overestimation of the effects of ship emissions on $\mathrm{O}_{3}$ of about $50 \%$ and on $\mathrm{OH}$ of roughly a factor of 2 . The differences are mainly caused by a strongly reduced lifetime (compared to background air) of $\mathrm{NO}_{\mathrm{x}}$ in the early stages of a ship plume.
\end{abstract}

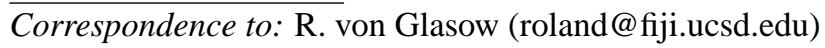

\section{Introduction}

The effects of the emissions of ships on cloud albedo were first described by Conover (1966). In the last decades many more studies dealt with the impact of ship exhaust on cloud albedo and microphysics (e.g. Coakley et al., 1987; Ackerman et al., 1995; Ferek et al., 1998; Durkee et al., 2000b). The impact of ship exhaust on the chemistry of the marine boundary layer (MBL), however, has only recently received attention. Streets et al. (1997) published estimates of $\mathrm{SO}_{2}$ emissions from international shipping in Asian waters and of the contribution of ship emissions to the deposition on land around the Asian waters. The first global compilation of $\mathrm{NO}_{\mathrm{x}}$ and $\mathrm{SO}_{2}$ emissions from ocean-going ships was presented by Corbett and Fischbeck (1997) and Corbett et al. (1999). They estimated global annual emissions of $\mathrm{NO}_{\mathrm{x}}$ to

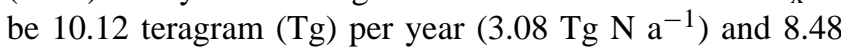
$\mathrm{Tg}$ of $\mathrm{SO}_{2}$ per year $\left(4.24 \mathrm{Tg} \mathrm{S} \mathrm{a}^{-1}\right)$ in 1993 . The sulfur emitted by ships corresponds to roughly $20 \%$ of the biogenic dimethylsulfide (DMS) emissions from the oceans. In some regions of the Northern Hemisphere ship emissions can be of the same order of magnitude as model estimates of the flux of DMS whereas they are much smaller than DMS emissions in the Southern Hemisphere. Streets et al. (2000) published updated values for the sulfur emissions in and sulfur deposition around Asian waters. They also estimated that ship emissions in the oceans off Asia increased by $5.9 \%$ yearly between 1988 and 1995.

Based on the emissions inventories by Corbett and Fischbeck (1997) and Corbett et al. (1999), Capaldo et al. (1999) used a global chemical transport model (CTM) to study the global effects of ship emissions on the sulfur cycle and the effect on radiative forcing. They found that ship emissions can

(C) European Geosciences Union 2003 
be a dominant contributor to $\mathrm{SO}_{2}$ concentrations over much of the world's ocean and in several coastal regions. Furthermore they estimated the global indirect radiative forcing due to ship derived particles to be $-0.11 \mathrm{~W} \mathrm{~m}^{-2}$. In ocean areas with busy ship traffic 30-50\% of the predicted non-sea salt sulfate was due to ship emissions and even in the Southern Hemisphere with very little ship traffic about $5 \%$ of the nss-sulfate was predicted to be derived from ship emissions.

In another study with a different global chemical transport model Lawrence and Crutzen (1999) investigated the effects of $\mathrm{NO}_{\mathrm{x}}$ emissions on the budget of $\mathrm{O}_{3}$ and $\mathrm{OH}$ and found that in heavily traversed ocean regions the $\mathrm{OH}$ burden was predicted to increase up to fivefold. This would reduce the atmospheric lifetimes of reactive trace gases and could have an effect on aerosol particle production and cloud properties as $\mathrm{OH}$ is an important oxidant for DMS. $\mathrm{O}_{3}$ concentrations were estimated to increase by a factor of more than 2 over the central North Atlantic and Pacific.

Using an updated emissions inventory and a different global model, Kasibhatla et al. (2000) qualitatively confirmed the effects predicted by Lawrence and Crutzen (1999), though due to a different geographic distribution of the emissions, the effects were more widespread and peak enhancements not as large. Comparing the model predictions with results from measurement campaigns they found a difference in $\mathrm{NO}_{\mathrm{x}}$ of about a factor of 10 , therefore showing no support for the model predicted enhancements of $\mathrm{NO}_{\mathrm{x}}$. They concluded that the parameterized description of plume dynamics and/or missing knowledge of the plume chemistry could be the cause for an overestimation of the effects of ship emissions.

Davis et al. (2001) used the global model of Kasibhatla et al. (2000) to further examine the issue using data taken over the north Pacific Ocean during five field campaigns over the time period 1991 to 1999 . They also found a tendency for this global model including ship emissions to overestimate the observed $\mathrm{NO}_{\mathrm{x}}$ levels by a factor of 3.3 during spring and a factor of 5 during fall. However, even without ships, their simulations overestimate the observed $\mathrm{NO}_{\mathrm{x}}$ by about $100 \%$, for unknown reasons (all numbers are from their Table 1). Davis et al. (2001) also proposed a possible reason for the large overestimate with ship emissions. The $\mathrm{OH}$ concentration is one of the main factors in determining the $\mathrm{NO}_{\mathrm{x}}$ lifetime (via reaction with $\mathrm{NO}_{2}$ to form $\mathrm{HNO}_{3}$, which is then generally deposited). $\mathrm{OH}$ concentrations depend strongly on $\mathrm{NO}_{\mathrm{x}}$ levels. They suggested that in plume air $[\mathrm{OH}]$ is high and therefore the $\mathrm{NO}_{\mathrm{x}}$ lifetime reduced, resulting in smaller $\mathrm{NO}_{\mathrm{x}}$ mixing ratios. This could help explain the tendency for global models to overestimate the observations because the different plume stages are not resolved in global models.

To yield a better understanding of the chemical processes and the importance of plume dilution we developed a box model to study these processes in detail. With the help of this model, we discuss ship plume chemistry in greater detail than previous studies; in particular we include in a simplistic way the dilution of a ship plume, which is highly concentrated directly after emission and subsequently diluted. Our box model includes detailed gas and aerosol phase chemistry as well as the entrainment of clean background air. We included halogen chemistry (bromine and chlorine released from sea salt aerosol) and emissions of aerosol particles by the ships. In Sect. 2 we describe the model and the treatment of the plume expansion. In Sect. 3 we discuss model results of a single plume in detail to point to the most important processes. In Sect. 4 we consider the effects of overlapping plumes and use an upscaling approach to assess potential global effects of ship emissions. Given the scarcity of field measurements and other studies this paper is of exploratory nature rather than trying to find final answers.

\section{Model description}

The time dependent photochemical box model employed here is based on an updated version of the box model MOCCA by Sander and Crutzen (1996) and Vogt et al. (1996) (the updated set of reactions can be found under http:// www.mpch-mainz.mpg.de/ $\sim$ sander/mocca). The model considers 131 gas phase (H-O-S-C-N-Br-Cl) reactions that are important for the chemistry of the MBL including halogen chemistry. A very comprehensive reaction set with 136 aqueous phase reactions, 11 heterogeneous reactions and 22 equilibria is used for sulfate and sea salt aerosols. We also included 4 irreversible heterogeneous reactions on soot aerosol. The model uses a Gear solver as part of the FACSIMILE software (Curtis and Sweetenham, 1987). The photolysis rates are calculated with a four-stream model using the approach of Brühl and Crutzen (1989).

For the study of ship exhaust we consider an idealized air parcel that is influenced by emissions of a ship that occur at a certain time by releasing a "puff" of ship exhaust. These emissions take place instantaneously, which is simulated by setting the concentrations of emitted gases and particles to values found in fresh plumes. Like in reality this air parcel is not further influenced by emissions from this ship. As soon as the emissions occur, the plume air begins mixing with background air. As the plume cross section increases due to entrainment of background air the plume air gets diluted. We prefer to describe the dilution of the polluted air as "entrainment of background air" to using the term "detrainment of polluted air" as we regard a single idealized air parcel that changes its volume. We calculate the chemical evolution of gas and aqueous phase species in the background and plume air separately and mixing between these regions is applied as discussed in the next section. This simplified approach enables us to study the plume over its complete lifetime. 


\subsection{Mixing of background and plume air}

The approach that is used for the mixing of plume and background air has been adopted from studies of the evolution of aircraft exhaust (e.g. Kärcher, 1999). The plume expansion in these parameterizations is described with an expansion coefficient that has to be determined empirically. In the description of point sources on the surface (e.g. power plant plumes) often Gaussian plume expansion is assumed (e.g. Seinfeld and Pandis, 1998). The parameters needed for the latter approach can be determined from atmospheric stability data with further assumptions on boundary conditions. Our approach is similar to the Gaussian approach with the main difference that in our approach the parameters used for the calculation of the plume expansion do not vary with time. A main restriction of both our and the Gaussian plume expansion approach is, that inhomogeneities perpendicular to the direction of ship movement of the plume evolution cannot be accounted for. This restriction can only be overcome with the use of three-dimensional models (e.g. Large Eddy Simulation (LES) models). We did not try to parameterize the in-plume inhomogeneities, but concentrated on the entrainment of background air into the ship plume.

For the box model two reservoirs of air are considered: the plume and the background reservoir. Both are assumed to be well-mixed. Dilution of the plume takes place by expansion of the plume and associated entrainment of background air. This means that we are effectively running two identical copies of the box model (one for each reservoir of air) at the same time with the same reactions, photolysis rates etc. but that ship emissions are considered only in one reservoir and that the undisturbed, background reservoir (which remains uninfluenced by the former one) serves only to provide the appropriate background concentrations of gases and particles for the entrainment (one-way coupling). We assume that mixing occurs only perpendicular to the ship's course (in the vertical and in the horizontal, see Fig. 1). The expansion of the plume can be formulated as:

$$
\begin{aligned}
& w_{p l}(t)=w_{0}\left(\frac{t}{t_{0}}\right)^{\alpha} \\
& h_{p l}(t)=h_{0}\left(\frac{t}{t_{0}}\right)^{\beta}
\end{aligned}
$$

where $w_{p l}$ and $h_{p l}$ are the width and height, respectively, of the plume at time $t, t_{0}$ is a reference time, here chosen to be $1 \mathrm{~s}$ after plume release and $w_{0}$ and $h_{0}$ are reference dimension of the plume at time $t_{0}$. They were estimated from data in the literature (see references in Table 1) to be $10 \mathrm{~m}$ and $5.5 \mathrm{~m}$, respectively, and correspond approximately to the cross-sectional area of a plume after 1 s. $\alpha$ and $\beta$ are the plume expansion rates in the horizontal and vertical, respectively. view from the side

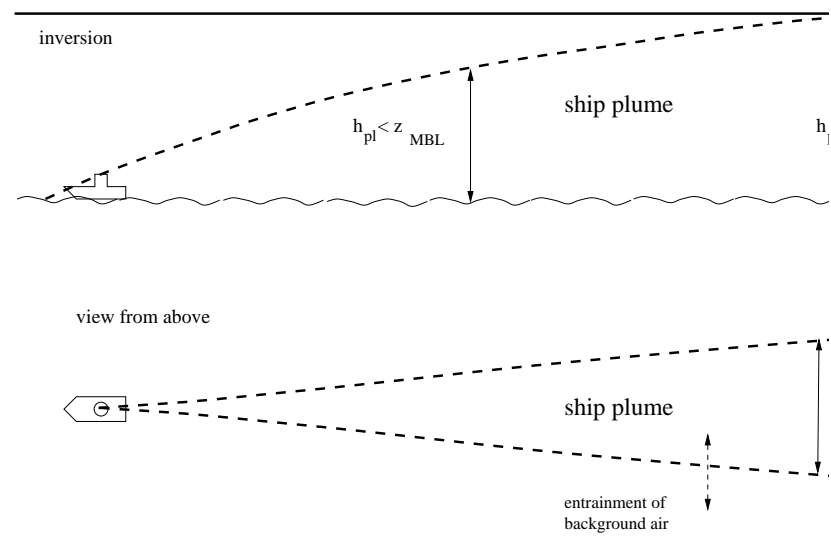

Fig. 1. Schematic of the assumed plume expansion. The bold horizontal line indicates the inversion that caps the MBL. The dashed lines show the extent of the ship plume.

The change in concentration in the plume $c_{p l}$ through mixing can be written as:

$\left.\frac{d c_{p l}}{d t}\right|_{\text {mix }}=\left(c_{b g}-c_{p l}\right) \frac{1}{A_{p l}} \frac{d A_{p l}}{d t}$

with the background concentration $c_{b g}$ and the cross section of the plume $A_{p l}$. The plume cross section (semi-ellipse) is given as $A_{p l}=\pi / 8 w_{p l} h_{p l}$. Using this definition for $A_{p l}$ one gets:

$$
\begin{aligned}
\frac{1}{A_{p l}} \frac{d A_{p l}}{d t} & =\frac{1}{\frac{\pi}{8} \frac{w_{0} h_{0}}{t_{0}^{\alpha} t_{0}^{\beta}} t^{\alpha+\beta}} \frac{\frac{\pi}{8} w_{0} h_{0}}{t_{0}^{\alpha} t_{0}^{\beta}}(\alpha+\beta) t^{\alpha+\beta-1} \\
& =\frac{\alpha+\beta}{t}
\end{aligned}
$$

The top of the MBL is assumed to be impenetrable by the plume, therefore the vertical expansion of the plume stops when $h_{p l}$ reaches $z_{M B L}$, which is the height of the MBL. Equation 3 can now be written as:

$\left.\frac{d c_{p l}}{d t}\right|_{\text {mix }}=\left\{\begin{array}{ll}\frac{\alpha+\beta}{t}\left(c_{b g}-c_{p l}\right) & h_{p l}(t)<z_{M B L} \\ \frac{\alpha}{t}\left(c_{b g}-c_{p l}\right) & h_{p l}(t)=z_{M B L}\end{array}\right.$.

Values for $\alpha$ and $\beta$ were estimated from the expansion of ship tracks as reported in the literature. The plume evolution is strongly dependent on atmospheric conditions like wind speed, wind shear, etc. It is therefore impossible to give numbers for $\alpha$ and $\beta$ that are valid for all atmospheric conditions. Table 1 lists the estimates of plume expansion derived from data found in the literature. "Best values" for $\alpha$ and $\beta$ were estimated and sensitivity studies performed to see the importance of the choice of these values. Our "best guess" for $\alpha$ of 0.75 is approximately the mean of the tabulated values. See the footnotes for details on the single cases. Durkee et al. (2000a) discuss a case of vertical plume dilution where first 
bright clouds (indicative of the ship pollution reaching the top of the MBL) appear about $1400 \mathrm{~s}$ after plume release in a $400 \mathrm{~m}$ deep MBL. Based on this, our "best guess" for $\beta$ is 0.6 .

Using the "best guess" values for $\alpha$ and $\beta$, the plume width after 1 hour is $4.6 \mathrm{~km}$ and the plume height about $750 \mathrm{~m}$ (unless the height of the MBL is smaller). The plume cross section increased from $55 \mathrm{~m}^{2}$ at $t_{0}$ to $3.5 \times 10^{6} \mathrm{~m}^{2}$ which corresponds to a dilution factor of $6.3 \times 10^{4}$.

An implicit assumption of the described implementation of mixing is that the plume is immediately well mixed and that the input of background air has an immediate influence on the chemistry of the complete plume. In reality one would expect higher concentrations of pollutants in the center of the plume cross section and lower values to the edges where clean air is mixed in. Further studies with three-dimensional models (e.g. Large Eddy Simulation (LES) models) should address this point.

The mass of the emitted compounds is conserved during the mixing process as the dilution of the plume air occurs only by entrainment of background air into the expanding plume and not by detrainment of plume air.

\subsection{Emission rate estimates}

Corbett et al. (1999) provided global estimates for the emissions of $\mathrm{SO}_{2}$ and NO. Their inventory is based on data and estimates of the global ship fleet and transport routes, fuel consumption, and emissions per consumed fuel. They used average $\mathrm{NO}_{\mathrm{x}}$ emission factors of $57 \mathrm{~g}\left(\mathrm{NO}_{2}\right) \mathrm{kg}_{\text {fuel }}^{-1}$ for medium-speed diesel engines and $87 \mathrm{~g}\left(\mathrm{NO}_{2}\right) \mathrm{kg}_{\text {fuel }}^{-1}$ for slowspeed engines from a Lloyd's study (Carlton et al., 1995). These numbers are similar to the numbers provided by EPA (2000). Massin and Herz (1993) cite data from the International Marine Organisation that list $\mathrm{NO}_{\mathrm{x}}$ emission factors of $70 \mathrm{~g} \mathrm{~kg}_{\text {fuel }}^{-1}$. According to EPA (2000) $94 \%$ of $\mathrm{NO}_{\mathrm{x}}$ is emitted as NO, so here we assume the same partitioning. Corbett and Fischbeck (1997) and Corbett et al. (1999), however, use $\mathrm{NO}_{2}$ as $\mathrm{NO}_{\mathrm{x}}$. This is accounted for in our calculations by considering only the nitrogen fluxes when we use their data. We use the EPA (2000) values for the in-plume concentrations of $\mathrm{NO}$ and $\mathrm{CO}$ because these values are estimated for fresh emissions and are consistent with the Corbett et al. (1999) data for an average cruise engine load of $80 \%$. Values for $\mathrm{SO}_{2}$ were estimated based on Corbett et al. (1999) and aldehyde emissions are expressed as $\mathrm{HCHO}$ according to EPA (1972) (see Table 2). No data for specified hydrocarbon emissions was found in the literature.

Hobbs et al. (2000) found that particles in ship tracks are mainly composed of organic material with high boiling points, possibly combined with sulfuric acid particles that were produced in the gas phase in the high $\mathrm{SO}_{2}$ regime of the plume. They found the typical water-soluble fraction of the particles to be $10 \%$. According to their volatility measurements, they are not composed of soot carbon.
Hobbs et al. (2000) estimated an average particle emission flux of $10^{16}$ part s$^{-1}$. Assuming an average ship speed of $10 \mathrm{~m} \mathrm{~s}^{-1}$ and a plume height and width $1 \mathrm{~s}$ after plume release of 10 and $5.5 \mathrm{~m}$, respectively (see above), the particle concentration would be about $1.8 \times 10^{7}$ part $\mathrm{cm}^{-3}$ after $1 \mathrm{~s}$. To account for the inaccuracies of this estimate we also did model runs with higher particle emission rates. Based on Hobbs et al. (2000) we assumed a monomodal lognormal size distribution for the emitted particles with a width of $\sigma=1.5$ and $r_{N}=0.04 \mu \mathrm{m}$. These particles are emitted into a background with 156 part $\mathrm{cm}^{-3}$ sulfate aerosols and 0.7 part $\mathrm{cm}^{-3}$ sea salt aerosols. As for gases the particles are emitted instantaneously when the idealized air parcel is crossed by a ship. In the model we assume that $10 \%$ of the dry aerosol nucleus that is emitted by the ship is soluble (pure $\mathrm{H}_{2} \mathrm{SO}_{4}$ ) and that the rest is insoluble. We also included the emission of soot particles. Dilution of the fresh plume with higher particle concentrations occurs very quickly (see Sect. 2.1), therefore we did not include aerosol particle collision and coalescence processes. Only the number density changes due to dilution. This assumption is confirmed by observations of ship emissions into a cloud-free MBL by Osborne et al. (2001) who did not observe a modal development of the aerosol spectra within the ship plume (Newport Bridge case-contrary to emissions into a cloudy MBL).

The measurements of Hobbs et al. (2000) did not show significant elevations of the mass concentrations of ions in bulk aerosol samples compared to the background. This is probably due to the small sizes and masses of the emitted particles.

\subsection{Chemistry in the plume}

A possible additional gas phase reaction in plume air with high $\mathrm{NO}_{\mathrm{x}}$ levels is the self-reaction of $\mathrm{NO}_{2}$ (DeMore et al., 1997). The product $\mathrm{N}_{2} \mathrm{O}_{4}$ is known to rapidly decompose thermally (DeMore et al., 1997) and to react slowly with water to $\mathrm{HONO}$ and $\mathrm{HNO}_{3}$ (England and Corcoran, 1974). The equilibrium constant for $\mathrm{NO}_{2}+\mathrm{NO}_{2} \longleftrightarrow \mathrm{N}_{2} \mathrm{O}_{4}$, however, gives an $\mathrm{N}_{2} \mathrm{O}_{4}$ mixing ratio of the order of $6 \mathrm{pmol} \mathrm{mol}^{-1}$ for an $\mathrm{NO}_{2}$ mixing ratio of $1 \mu \mathrm{mol} \mathrm{mol}^{-1}$, so that formation of $\mathrm{N}_{2} \mathrm{O}_{4}$ is expected not to play a role, which was confirmed by inclusion of these reactions into the model. Other unusual reactions within the $\mathrm{NO}_{\mathrm{x}}$ family likewise do not play a role after the first seconds following plume emission because they either are too slow ( $\mathrm{NO}+\mathrm{NO}+\mathrm{O}_{2} \longrightarrow 2 \mathrm{NO}_{2}$, Atkinson et al., 1997) or have fast backward reactions (NO $+\mathrm{NO}_{2} \longleftrightarrow \mathrm{N}_{2} \mathrm{O}_{3}$, Atkinson et al., 1997).

If combustion derived soot particles would be emitted by ships, they could have an influence on the chemistry, e.g. by converting $\mathrm{NO}_{2}$ in a heterogeneous reaction to $\mathrm{HONO}$ (Kalberer et al., 1996; Ammann et al., 1998). HONO rapidly photolyzes, thereby producing $\mathrm{OH}$ and NO. The production of $\mathrm{OH}$ in this reaction could compensate for a reduced production of $\mathrm{OH}$ from $\mathrm{O}_{3}$ photolysis $\left(\mathrm{O}_{3}\right.$ concentrations are 
Table 1. Estimates of values for $\alpha$

\begin{tabular}{lllll}
\hline source & ship track width & distance from ship & time since emission & derived $\alpha$ \\
\hline $\begin{array}{l}\text { Durkee et al. (2000a), ship } \\
\text { moves into wind, A }\end{array}$ & $3100 \mathrm{~m}$ & $40000 \mathrm{~m}$ & $3390 \mathrm{~s}^{a}$ & 0.71 \\
$\begin{array}{l}\text { Durkee et al. (2000a), ship } \\
\text { moves into wind, B }\end{array}$ & $3800 \mathrm{~m}$ & $40000 \mathrm{~m}$ & $1710 \mathrm{~s}^{a}$ & 0.80 \\
$\begin{array}{l}\text { Durkee et al. (2000a), ship } \\
\text { moves with wind, C }\end{array}$ & $10500 \mathrm{~m}$ & $40000 \mathrm{~m}$ & $7690 \mathrm{~s}^{a}$ & 0.78 \\
$\begin{array}{l}\text { Durkee et al. (2000a), ship } \\
\text { moves with wind, D }\end{array}$ & $6100 \mathrm{~m}$ & $40000 \mathrm{~m}$ & 0.70 \\
$\begin{array}{l}\text { Ferek et al. (1998) } \\
\text { "best guess" }\end{array}$ & $7500 \mathrm{~m}$ & $20000 \mathrm{~s}$ & 0.67 \\
\hline
\end{tabular}

${ }^{a}$ Calculated based on relative windspeeds as given in Durkee et al. (2000a). ${ }^{b}$ Rough estimate from Fig. 2 in Ferek et al. (1998); $\alpha$ is calculated with Eq. (1). The letters A-D indicate the cases discussed in Durkee et al. (2000a).

Table 2. Emissions strength of gases

\begin{tabular}{|c|c|c|c|c|}
\hline & $\mathrm{NO}_{\mathrm{x}}{ }^{a}$ & $\mathrm{CO}$ & $\mathrm{SO}_{2}$ & $\mathrm{HCHO}$ \\
\hline emission $\left(\mathrm{g} \mathrm{kWh}^{-1}\right)$ & $10^{b}$ & $1^{b}$ & & \\
\hline emission factor $\left(\mathrm{g} \mathrm{kg}_{\text {fuel }}^{-1}\right)$ & $50^{c}$ & $5^{c}$ & $40^{d}$ & \\
\hline exhaust mixing ratio $\left(\mu \mathrm{mol} \mathrm{mol}{ }^{-1}\right)$ & $1000^{b}$ & $100^{b}$ & $360^{e}$ & $5^{f}$ \\
\hline
\end{tabular}

${ }^{a}$ We used a NO: $\mathrm{NO}_{2}$ ratio 96:4 (EPA, 2000) ${ }^{b}$ From EPA (2000) for a typical engine load of $80 \%$. ${ }^{c}$ Calculated using a typical fuel

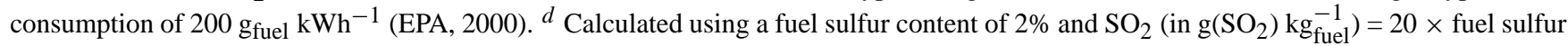
content (in \%) (Corbett et al., 1999). ${ }^{e}$ Calculated from the data given previously, yielding a molar ratio of 0.36 between the mixing ratios of $\mathrm{SO}_{2}$ and NO in the exhaust. ${ }^{f} 0.05 \times \mathrm{CO}$ (EPA, 1972, they expressed aldehyde emissions as HCHO).

low in the early plume stages). Soot particles that are emitted by ships might change their composition and surface properties very rapidly. As no experimental data on that is available we could not consider this. We use the term "soot" but are well aware that "ship derived carbonaceous particles with the specified surface properties" would be a more correct way of describing them. There is a clearly a need for more experimental data regarding the composition and concentrations of ship derived particles.

Many studies have dealt with heterogeneous reactions on various types of soot surfaces. These studies where mainly done in Knudsen cells or in aerosol flow reactors and resulted in sometimes very high uptake coefficients of e.g. $\mathrm{NO}_{2}$ of the order of $10^{-2}$ on soot surfaces (Rogaski et al., 1997; Gerecke et al., 1998). Other studies found uptake rates that were several orders of magnitude lower (Kalberer et al., 1996; Ammann et al., 1998; Longfellow et al., 1999; Al-Abadleh and Grassian, 2000; Kirchner et al., 2000), surface saturation effects that result in a time dependence of the uptake (Ammann et al., 1998; Longfellow et al., 1999; Al-Abadleh and Grassian, 2000; Kirchner et al., 2000) and also a strong dependency on the type of soot used (Kalberer et al., 1996; Kirchner et al., 2000). Recent papers by Kamm et al. (1999) and
Saathoff et al. (2001) show results from a very large aerosol chamber (AIDA, $84 \mathrm{~m}^{3}$ volume) where spark discharge produced soot particles were used. They found that only reactive uptake of $\mathrm{HO}_{2}$ occured on timescales that are relevant for the atmosphere.

The differences in the above cited studies make it very difficult to choose the parameters for the reactive uptake on soot particles. We assumed the following accommodation coefficients: $\alpha\left(\mathrm{NO}_{2}\right)=1.6 \times 10^{-4}$ with the formation of $\mathrm{HONO}$ (Aumont et al., 1999), $\alpha\left(\mathrm{NO}_{2}\right)=3.0 \times 10^{-4}$ with the subsequent reaction to NO $\left(\mathrm{k}=10^{-3} \mathrm{~s}^{-1}\right)$ (Aumont et al., 1999), $\alpha\left(\mathrm{N}_{2} \mathrm{O}_{5}\right)=6.3 \times 10^{-3}$ with the formation of $\mathrm{NO}_{2}$ (Longfellow et al., 2000), $\alpha\left(\mathrm{HNO}_{3}\right)=1 \times 10^{-4}$ (physical adsorption, highest value from Kirchner et al., 2000), $\alpha\left(\mathrm{HO}_{2}\right)=1 \times 10^{-2}$ (upper limit from Saathoff et al., 2001). Note that almost all laboratory studies could not derive accomodation coefficients but only effective uptake coefficients, usually denoted as $\gamma$. In the model we calculate the gas phase loss rates for reactions on soot according to equations 11-14 in Sander and Crutzen (1996) but assume them to be irreversible. This implies the use of accommodation coefficients (see also Sander (1999) for a more detailed discussion of accommodation coefficients). Gas phase diffusion is explicitly accounted for. 

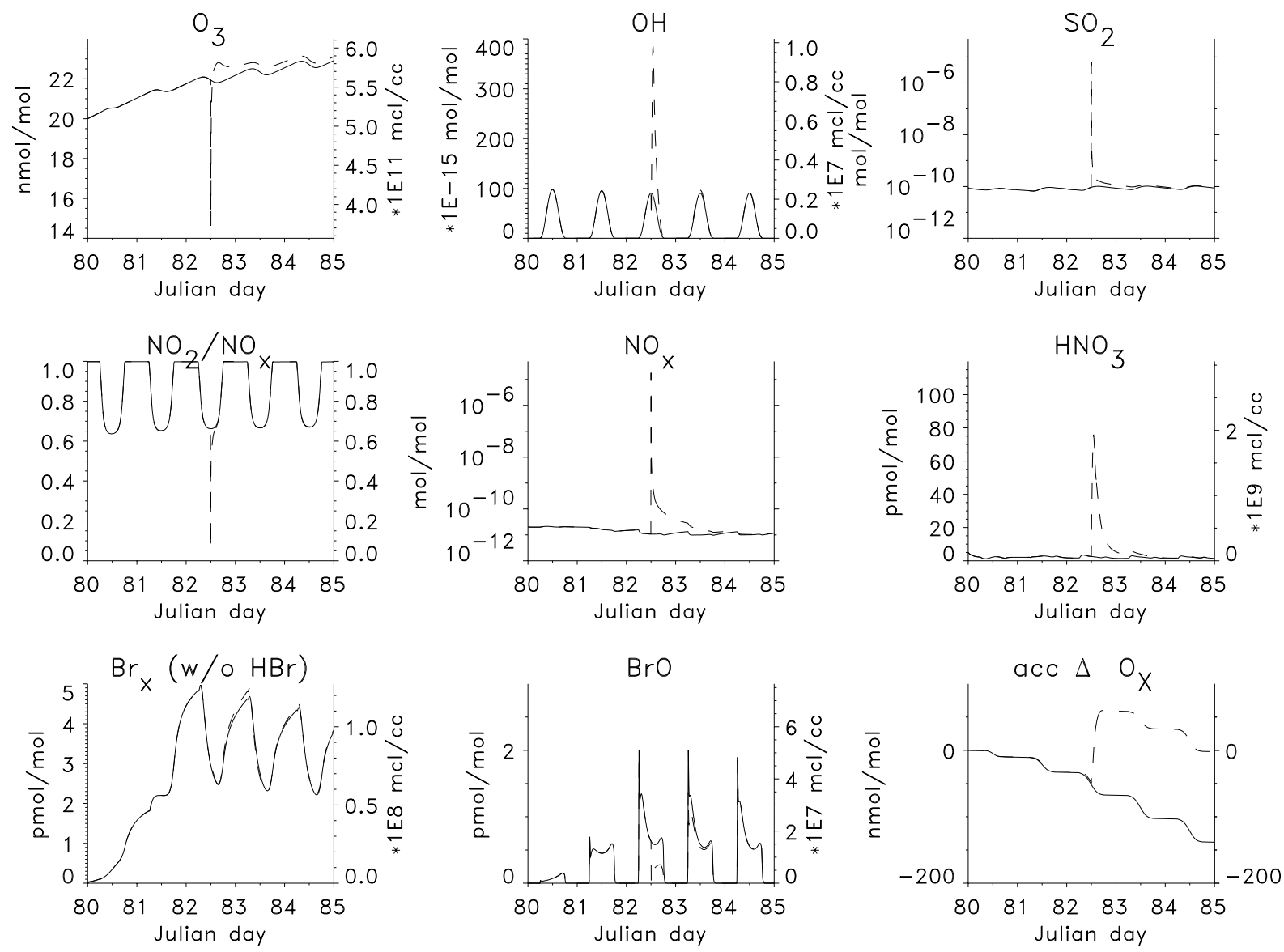

Fig. 2. Development with time of the major gas phase species and accumulated $\Delta \mathrm{O}_{\mathrm{x}}$ in undisturbed background air (solid line) and plume air (dashed line). Emission of the ship plume is at 12:00 on the third day (=Julian day 82). Note that immediately after plume release almost all $\mathrm{O}_{3}$ is destroyed which is not shown on the figure due to an output timestep of 5 minutes.

The use of the values for effective uptake coefficients $(\gamma)$ as accommodation coefficients $(\alpha)$ might lead to an underestimate of the overall loss rate. We tested this and found that the differences in loss rate coefficients were less than $1 \%$.

Note that (Kirchner et al., 2000) found distinctly smaller uptake coefficients for $\mathrm{NO}_{2}$ for various types of soot, but especially for diesel car soot which is thought to be most representative for ship emissions. Therefore the estimates that we used are clearly upper limits. According to Kamm et al. (1999) and Disselkamp et al. (2000) we do not assume heterogeneous uptake of $\mathrm{O}_{3}$ on soot. The surface of soot and therefore the uptake properties are subject to changes during the atmospheric lifetime of soot. Due to incomplete knowledge of this process we assumed no dependence with time of the uptake reactions.

We want to stress that still a lot of information on heterogeneous reactions on carbonaceous/soot aerosol particles is uncertain or missing which makes an assessment of these processes difficult. Therefore we chose for most parameters (emission strength, plume dilution, time of plume release, $\alpha$ etc.) the values in such a way that we get a best possible estimate or, if the data were too uncertain, an upper limit.

\section{Effects of emissions of a single ship}

In this section we discuss in detail the chemical devlopment of the exhaust plume of a single ship. We investigated the effects of different initial values of the background $\mathrm{NO}_{\mathrm{x}}$ and $\mathrm{O}_{3}$ concentrations (Sect. 3.2), of the local time of plume emission (Sect. 3.3), of different plume expansion rates (different values for $\alpha$, Sect. 3.4), of aerosol chemistry (Sect. 3.5), and of the emissions strength and $\mathrm{NO}: \mathrm{NO}_{2}$ ratio (Sect. 3.6). All model runs were made for cloud-free conditions. To be able to concentrate on effects of changing individual parameters we chose to use the same meteorological conditions for all runs that we describe here. The temperature is $15^{\circ} \mathrm{C}$, the relative humidity $81 \%$ and the depth of the marine boundary layer is $750 \mathrm{~m}$. The photolysis rates are calculated for a geographical latitude of $45^{\circ}$ with an $\mathrm{O}_{3}$ column of $300 \mathrm{DU}$. The model runs start on Julian day 80 . First we discuss the features of the base run. 


\subsection{Base run}

The base run includes background aerosol particles as well as emission of partly soluble particles $\left(1.82 \times 10^{7} \mathrm{~cm}^{-3}\right.$ one second after puff release) and soot particles $\left(1 . \times 10^{5} \mathrm{~cm}^{-3}\right.$ one second after puff release). The ship plume is emitted at 12:00 local time on the third model day to allow a model spin-up time of 2.5 days. The initial $\mathrm{NO}_{\mathrm{x}}$ mixing ratio $\left(\left[\mathrm{NO}_{\mathrm{x}}\right]_{0}\right)$ is $20 \mathrm{pmol} \mathrm{mol}^{-1}$ and the initial $\mathrm{O}_{3}$ mixing ratio is $20 \mathrm{nmol} \mathrm{mol}^{-1}$. We included a constant $\mathrm{O}_{3}$ source of 2.3 pmol mol ${ }^{-1}$ day $^{-1}$ to yield approximately constant $\mathrm{O}_{3}$ concentrations after the halogen chemistry has fully developed. Chemical reactions lead to a net chemical $\mathrm{O}_{3}$ destruction as explained below. All $\mathrm{C} 2$ and higher alkanes and alkenes are lumped with initial mixing ratios of $500 \mathrm{pmol} \mathrm{mol}^{-1}$ and $50 \mathrm{pmol} \mathrm{mol}^{-1}$, respectively.

Figure 2 shows a comparison of the evolution of the mixing ratios in background and plume air. In all of the studied cases the overall evolution of the plume air is similar: $\mathrm{O}_{3}$ is destroyed immediately after plume release by reaction with $\mathrm{NO}$, minimal mixing ratios are close to zero in the first few seconds after plume emission. This is not visible in the plot as the output timestep is $5 \mathrm{~min}$ and by this time $\mathrm{O}_{3}$ has already been reformed and entrained. Later $\mathrm{O}_{3}$ is produced by $\mathrm{NO}_{\mathrm{x}}$ catalyzed hydrocarbon oxidation reactions. The maximum increase in $\mathrm{O}_{3}$ in the plume air compared to the background air is small, about $1 \mathrm{nmol} \mathrm{mol}^{-1}$ (i.e. 5\%). Directly after plume emission $[\mathrm{OH}]$ decreases due to the strong emissions of $\mathrm{CO}$ but then $\mathrm{OH}$ is reformed by the reactions $\mathrm{HO}_{2}+\mathrm{NO}$ and $\mathrm{CH}_{3} \mathrm{OO}+\mathrm{NO}$. The maximum value of $\mathrm{OH}$ is $1.1 \times 10^{7}$ molec $\mathrm{cm}^{-3}$ (i.e. $340 \%$ increase) on the first day immediately after plume emission. The maximum increase in $\mathrm{HNO}_{3}$ is about $70 \mathrm{pmol} \mathrm{mol}{ }^{-1}$. Maximum mixing ratios are $18 \mu \mathrm{mol} \mathrm{mol}^{-1}$ for $\mathrm{NO}_{\mathrm{x}}$ and $6.5 \mu \mathrm{mol} \mathrm{mol}{ }^{-1}$ for $\mathrm{SO}_{2}$, these are determined by the assumed exhaust mixing ratios. Immediately after release of the "puff" the $\mathrm{NO}_{\mathrm{x}}$ mixing ratios are dramatically reduced, mainly by expansion of the plume. Chemical loss of $\mathrm{NO}_{\mathrm{x}}$ occurs via the production of $\mathrm{HNO}_{3}$ as a product of the reaction $\mathrm{OH}+\mathrm{NO}_{2} \cdot \mathrm{HNO}_{3}$ is then either deposited on the sea surface or taken up by particles.

To evaluate the production of ozone, the odd oxygen family $\mathrm{O}_{\mathrm{x}}$ is defined based on Crutzen and Schmailzl (1983): $\mathrm{O}_{\mathrm{x}}$ $=\mathrm{O}_{3}+\mathrm{O}+\mathrm{O}\left({ }^{1} \mathrm{D}\right)+\mathrm{NO}_{2}+2 \mathrm{NO}_{3}+3 \mathrm{~N}_{2} \mathrm{O}_{5}+\mathrm{HNO}_{4}+\mathrm{ClO}$ $+2 \mathrm{Cl}_{2} \mathrm{O}_{2}+2 \mathrm{OClO}+\mathrm{BrO}$. The accumulated change in $\mathrm{O}_{\mathrm{x}}$ (shown as "acc $\Delta \mathrm{O}_{\mathrm{x}}$ " in the figures) accounts only for chemical $\mathrm{O}_{\mathrm{x}}$ destruction and production. In the background air net chemical $\mathrm{O}_{\mathrm{x}}$ destruction occurs due to the low $\mathrm{NO}_{\mathrm{x}}$ mixing ratios. After plume release there is a large difference in net chemical $\mathrm{O}_{\mathrm{x}}$ change between the background and plume air, with production in the plume. Most of this production occurs in the first few hours after plume release. For the base run the increase in $\mathrm{O}_{\mathrm{x}}$ is about $3 \mathrm{nmol} \mathrm{mol}^{-1}$ (note that the accumulated $\mathrm{O}_{\mathrm{x}}$ rates in the plots do not show the titration of $\mathrm{O}_{3}$ by $\mathrm{NO}$ in the early plume stage because the produced $\mathrm{NO}_{2}$ is part of the $\mathrm{O}_{\mathrm{x}}$ family).
As a consequence of the uptake of $\mathrm{HNO}_{3}$ by the sea salt aerosol, acid displacement occurs and $\mathrm{HCl}$ degasses from the sea salt aerosol, increasing the $\mathrm{HCl}$ mixing ratio from about $10 \mathrm{pmol} \mathrm{mol}^{-1}$ to a maximum of $35 \mathrm{pmol} \mathrm{mol}^{-1}$ in the fresh plume. Through a series of reactions (see Sander and Crutzen, 1996; Vogt et al., 1996; Fickert et al., 1999) reactive bromine and chlorine species are released from sea salt aerosol, that might have an influence on the gas phase chemistry. Also, the high $\mathrm{NO}_{\mathrm{x}}$ reactions initiate reaction cycles involving halogenated nitrogen oxides (see Finlayson-Pitts and Hemminger, 2000, for an overview).

In the model an autocatalytic cycle takes place under clean conditions that leads to the release of bromine $\left(\mathrm{Br}_{2}, \mathrm{BrCl}\right)$ from the sea salt aerosol. These species photolyze, produce the $\mathrm{Br}$ radical, which subsequently reacts with $\mathrm{O}_{3}$, forming $\mathrm{BrO}$. $\mathrm{BrO}$ reacts with $\mathrm{HO}_{2}$ to $\mathrm{HOBr}$ which is taken up by the aerosol thereby closing the reaction cycle. For more details see Sander and Crutzen (1996), Vogt et al. (1996), or von Glasow et al. (2002c). In the fresh plume, BrO mixing ratios decrease due to the high NO concentration in the reaction:

$\mathrm{NO}+\mathrm{BrO} \longrightarrow \mathrm{NO}_{2}+\mathrm{Br}$.

This reaction reduces $\mathrm{BrO}$ strongly but it has no net effect on $\mathrm{O}_{\mathrm{x}}$ because both $\mathrm{BrO}$ and $\mathrm{NO}_{2}$ are members of the $\mathrm{O}_{\mathrm{x}}$ family. In the reaction of $\mathrm{BrO}$ with $\mathrm{NO}_{2}, \mathrm{BrNO}_{3}$ is formed and further reactions involving the aerosol phase (Sander et al., 1999) can lead to formation of $\mathrm{HOBr}$ and the liberation of $\mathrm{Br}_{2}$ and $\mathrm{BrCl}$ from the particles and the subsequent loss of $\mathrm{O}_{\mathrm{x}}$ by halogen reactions.

This bromine activation cycle, however, cannot balance the decline in $\mathrm{HOBr}$ production by $\mathrm{BrO}+\mathrm{HO}_{2}$, as both $\mathrm{BrO}$ and $\mathrm{HO}_{2}$ are strongly reduced in the highly concentrated plume. The production of $\mathrm{HBr}$ in the plume leads to a decrease in $\mathrm{Br}_{\mathrm{x}}$ (which is the sum of all gas phase bromine species except $\mathrm{HBr}$ ) on the first day after plume emission. Only later when NO mixing ratios are already small due to dilution, an increase in $\mathrm{Br}_{\mathrm{x}}$ in the plume compared to the background can be seen in all runs except for the one with slow plume evolution. This is caused by reactions involving $\mathrm{BrNO}_{3}$.

Through reactions on the sea salt surface and reactions in the gas phase, $\mathrm{Cl}_{2}$ is also formed in the plume air, where mixing ratios are up to twice as high as in the background air. The concentration of $\mathrm{Cl}$ increases from $10^{3}$ atoms $\mathrm{cm}^{-3}$ to a maximum of to $3 \times 10^{4}$ atoms $\mathrm{cm}^{-3}$. This maximum is, however, too short lifed to be of importance for the chemistry.

Differences between background and plume concentrations of more than $10 \%$ are present for $\mathrm{OH}$ only on the first day and for $\mathrm{SO}_{2}, \mathrm{NO}_{\mathrm{x}}$ and $\mathrm{HNO}_{3}$ on the first and second day after plume release. Two days after plume release when the plume reached a width of $85 \mathrm{~km}$ the difference between background and plume air is below $5 \%$ for all species. We define the "chemical lifetime" of the plume to be the time until the concentrations in the plume are essentially the same as in background air. This leads to a chemical lifetime of about 

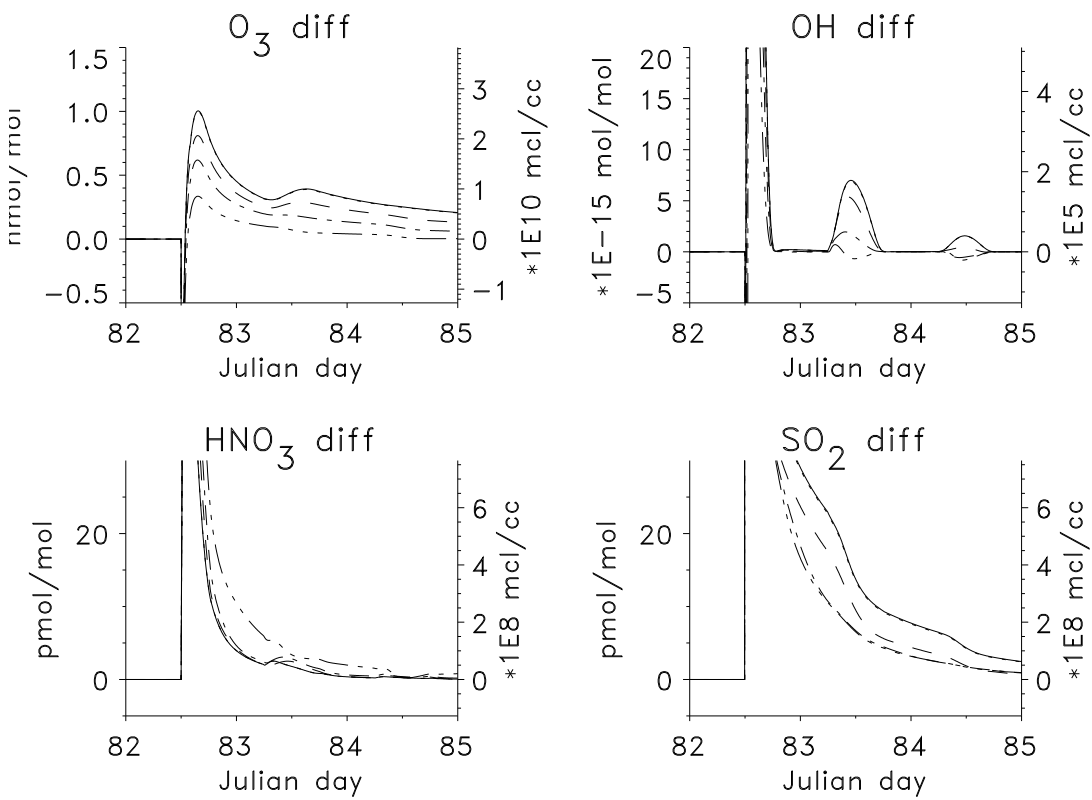

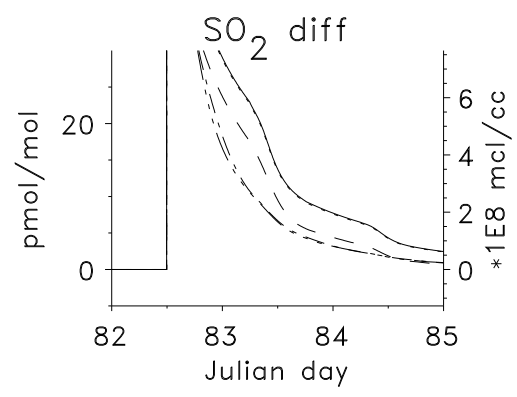

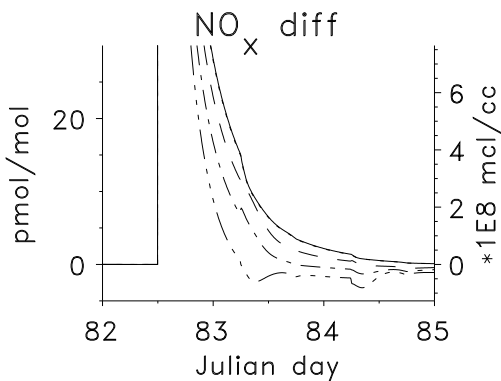

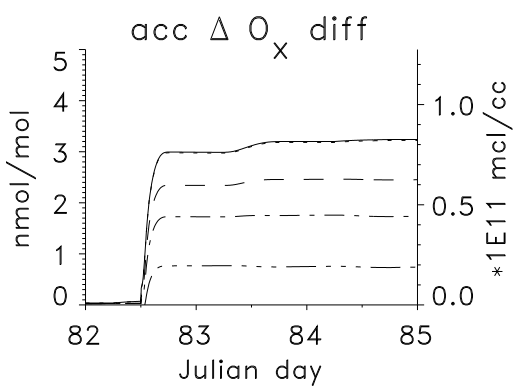

Fig. 3. Differences between plume and undisturbed background air in the evolution with time of the major gas phase species and accumulated $\mathrm{O}_{\mathrm{x}}$ production rates for emission of a ship plume at 12:00 on the third day (=Julian day 82). The lines show runs with different background $\mathrm{NO}_{\mathrm{x}}$ mixing ratios: solid line: $5 \mathrm{pmol} \mathrm{mol}{ }^{-1}$; dotted: $20 \mathrm{pmol} \mathrm{mol}^{-1}$; dashed: $100 \mathrm{pmol} \mathrm{mol}^{-1}$; dash-dotted: $200 \mathrm{pmol} \mathrm{mol}^{-1}$; dash-dotdot: $500 \mathrm{pmol} \mathrm{mol}^{-1}$. The difference between the run with 5 and $20 \mathrm{pmol} \mathrm{mol}^{-1}$ is barely visible. The initial background mixing ratio of $\mathrm{O}_{3}$ is $20 \mathrm{nmol} \mathrm{mol}^{-1}$ and that of $\mathrm{SO}_{2}$ is $90 \mathrm{pmol} \mathrm{mol}^{-1}$.

2 days. Note that the mean lifetime of $7.3 \mathrm{~h}$ that was derived during the MAST campaign (Durkee et al., 2000a) is based on a different definition, namely on cloud albedo effects as measured from satellites. The most dramatic reductions in pollutant concentrations of course occur during the first hour after plume release. Our definition of chemical lifetime is meant to indicate when an airmass that was influenced by a ship can no longer be distinguished from one that was not perturbed. It has to be stressed that this result is strongly dependent on atmospheric mixing (see Sect. 3.4).

It is important to point to the differences in $\mathrm{NO}_{\mathrm{x}}$ lifetime in the early plume stages. The instantaneous lifetime is reduced from about $17.5 \mathrm{~h}$ in background air to $4.5 \mathrm{~h}$ in plume air directly after plume emission. See also Sect. 4.2 for further discussion of the $\mathrm{NO}_{\mathrm{x}}$ lifetime and comparison to the lifetimes if the plume is treated as a continous source.

The lifetime of $\mathrm{SO}_{2}$ is influenced less because loss via oxidation by $\mathrm{OH}$ is only a minor factor. In background air its lifetime against oxidation by $\mathrm{OH}$ is of the order of 10 days and if oxidation in aerosol particles is included it is still about 7 days (all data from von Glasow et al., 2002b). In cloud free plume air the instantaneous lifetime of $\mathrm{SO}_{2}$ against oxidation by $\mathrm{OH}$ is reduced by only $50 \%$.

\subsection{Background $\mathrm{NO}_{\mathbf{x}}$ and $\mathrm{O}_{3}$}

We varied the background $\mathrm{NO}_{\mathrm{x}}$ mixing ratios between 5 pmol mol ${ }^{-1}$ and $500 \mathrm{pmol} \mathrm{mol}^{-1}$. In the runs with high initial background concentrations of $\mathrm{NO}_{\mathrm{x}}$ these high values were artificially sustained by corresponding $\mathrm{NO}_{\mathrm{x}}$ sources to see the effect of ship emissions in high $\mathrm{NO}_{\mathrm{x}}$ regimes, e.g. coastal regions. For runs with initial $\mathrm{NO}_{\mathrm{x}}$ mixing ratios above $50 \mathrm{pmol} \mathrm{mol}^{-1}, \mathrm{O}_{3}$ is produced in the background air, in the runs with lower initial $\mathrm{NO}_{\mathrm{x}}, \mathrm{O}_{3}$ is destroyed.

In Fig. 3 the evolution with time of the major gas phase species for the runs with initial $\mathrm{NO}_{\mathrm{x}}$ mixing ratios of 5 to $500 \mathrm{pmol} \mathrm{mol}^{-1}$ is depicted. Shown are the differences between undisturbed background and plume air (e.g. $\mathrm{O}_{3}$ diff). Parts of the graphs are outside the plotting region, because the maxima are mainly determined by the in-plume values and for our discussion the plume development after the first few hours is most relevant and not the maximum differences.

The maximum increase in $[\mathrm{OH}]$ is between $7.5 \times 10^{6}$ molec $\mathrm{cm}^{-3}$ for the run with $\left[\mathrm{NO}_{\mathrm{x}}\right]=5 \mathrm{pmol} \mathrm{mol}^{-1}$ and 2.8 $\times 10^{6} \mathrm{molec} \mathrm{cm}^{-3}$ for the run with $\left[\mathrm{NO}_{\mathrm{x}}\right]=500 \mathrm{pmol} \mathrm{mol}^{-1}$ on the second day after plume release. The difference in $\mathrm{NO}_{\mathrm{x}}$ between background and plume air is reduced quicker in the cases with high initial $\mathrm{NO}_{\mathrm{x}}$ concentrations because more $\mathrm{HNO}_{3}$ is produced due to the higher $\mathrm{OH}$ concentrations. The maximum increase in $\mathrm{HNO}_{3}$ is about $70 \mathrm{pmol} \mathrm{mol}^{-1}$ for the run with $\left[\mathrm{NO}_{\mathrm{x}}\right]=5 \mathrm{pmol} \mathrm{mol}^{-1}$ and $100 \mathrm{pmol} \mathrm{mol}^{-1}$ for the run with $\left[\mathrm{NO}_{\mathrm{x}}\right]=500 \mathrm{pmol} \mathrm{mol}^{-1}$. Note that in the runs with higher initial $\mathrm{NO}_{\mathrm{x}}$ mixing ratios there is less $\mathrm{NO}_{\mathrm{x}}$ in the plume air than in the background on the second and third day after plume release. This effect is quantitatively not important and caused by uptake of $\mathrm{XNO}_{3}(\mathrm{X}=\mathrm{Br}, \mathrm{Cl})$ on the 
ship derived partly soluble sulfate particles and subsequent reactions among the different $\mathrm{NO}_{\mathrm{y}}$ species.

Naturally the change in the $\mathrm{O}_{\mathrm{x}}$ budget due to the ship emissions of about 0.8 to $3 \mathrm{nmol} \mathrm{mol}{ }^{-1}$ on the first day after plume release is less important for the runs with already high $\mathrm{O}_{\mathrm{x}}$ production. For the runs with net $\mathrm{O}_{3}$ destruction in the background air (i.e. runs with initial $\mathrm{NO}_{\mathrm{x}}$ below 50 pmol mol${ }^{-1}$ ) this is a major change in the chemistry because the system moved in the plume air from $\mathrm{O}_{\mathrm{x}}$ destruction to $\mathrm{O}_{\mathrm{x}}$ production. For the $\mathrm{NO}_{\mathrm{x}}=5 \mathrm{pmol} \mathrm{mol}^{-1}$ run the background $\mathrm{O}_{\mathrm{x}}$ destruction is roughly $0.8 \mathrm{nmol} \mathrm{mol}^{-1}$ day $^{-1}$ whereas for the $\mathrm{NO}_{\mathrm{x}}=500 \mathrm{pmol} \mathrm{mol}^{-1}$ run the background $\mathrm{O}_{\mathrm{x}}$ production is about $5.6 \mathrm{nmol}^{-1} \mathrm{day}^{-1}$. Note that not only the relative but also the absolute changes in $\mathrm{O}_{3}$ and other trace gases are less pronounced in the runs with high initial $\mathrm{NO}_{\mathrm{x}}$. This is caused by the high background $\mathrm{NO}_{\mathrm{x}}$ concentrations that already lead to significant $\mathrm{O}_{\mathrm{x}}$ production and high $\mathrm{O}_{3}$ levels in the background. These need to be replenished by chemical production and entrainment after the titration of $\mathrm{O}_{3}$ in the first minutes after plume release.

Effects on $\mathrm{NO}_{\mathrm{x}}$ lifetime reduction in the plume are a lot less pronounced in the runs with high $\left[\mathrm{NO}_{\mathrm{x}}\right]_{0}$ because of already high $\mathrm{OH}$ concentrations in the background air. In the run with $\left[\mathrm{NO}_{\mathrm{x}}\right]_{0}=500 \mathrm{pmol} \mathrm{mol}^{-1}$ the $\mathrm{OH}$ concentration at noon before plume emission is about $1 \times 10^{7}$ molec cm$~^{-3}$ implying an instantaneous $\mathrm{NO}_{\mathrm{x}}$ lifetime of $3.6 \mathrm{~h}$. The relative increase of $[\mathrm{OH}]$ is only $14 \%$ (compared to $330 \%$ in the base run) and the decrease of the $\mathrm{NO}_{\mathrm{x}}$ lifetime is only about $15 \%$.

In summary, the impact and lifetime of ship emissions are largest for the run with the smallest $\mathrm{NO}_{\mathrm{x}}$ background mixing ratios. The reason for this lies in the small $\mathrm{OH}$ concentrations for the runs with low $\mathrm{NO}_{\mathrm{x}}$. As $\mathrm{OH}$ is the most important gas phase sink for $\mathrm{NO}_{\mathrm{x}}$ and $\mathrm{SO}_{2}$, these low background concentrations of $\mathrm{OH}$ result in the largest differences between plume and background concentrations of $\mathrm{NO}_{\mathrm{x}}$ and $\mathrm{SO}_{2}$ in the runs with smallest initial $\mathrm{NO}_{\mathrm{x}}$ mixing ratios.

A similar result was found when the initial $\mathrm{O}_{3}$ mixing ratio was varied between 10 and $50 \mathrm{nmol} \mathrm{mol}^{-1}$ (not shown). The effects of ship emissions are strongest and most persistent for low $\mathrm{O}_{3}$ regimes.

\subsection{Plume emission time}

When ship emissions occur during night, $\mathrm{NO}_{3}$ and $\mathrm{N}_{2} \mathrm{O}_{5}$ (which is taken up by the particles) are formed and due to the lack of $\mathrm{OH}$ the transformation of $\mathrm{NO}_{\mathrm{x}}$ to $\mathrm{HNO}_{3}$ is slowed down compared to cases with emissions during the day. We did runs with plume emission time at 6:00, 12:00 (base run), 18:00 and 24:00 local time. Overall the effects are more pronounced when emissions occur during day when the photochemistry is active. Accumulated $\mathrm{O}_{\mathrm{x}}$ production decreased from about $3 \mathrm{nmol} \mathrm{mol}^{-1}$ in the base case to roughly $0.5 \mathrm{nmol} \mathrm{mol}^{-1}$ in the case with plume release at 18:00 local time. Peak mixing ratios of $\mathrm{HNO}_{3}$ decreased also sig- nificantly to about $20 \mathrm{pmol} \mathrm{mol}^{-1}$ if the emission occured during night. The "slower" chemistry during night (due to the lack of photochemistry) increases the importance of entrainment of background air. The decrease of $\mathrm{NO}_{\mathrm{x}}$ and $\mathrm{SO}_{2}$ is similar for all runs indicating that during the first day this is mainly determined by dilution of the plume.

When emissions occur during night, when the lifetime of most species is greater than during the day, reservoir species can be formed in the plume air. They have the potential to be transported to regions that have previously been unaffected by ship emissions. Reservoir species can also be formed in cold regions from species that are mainly destroyed by thermolysis (similar to PAN). Therefore the longrange effect of ship emissions would be most pronounced in high latitude winters.

\subsection{Influence of mixing}

To study the influence of dilution on the evolution of the plume, different values for $\alpha$, the horizontal plume expansion rate, were used. Values of $\alpha=0.62$ (plume width after 2.5 days $=20 \mathrm{~km}), \alpha=0.75(100 \mathrm{~km}$, "best guess"), $\alpha=0.87(438 \mathrm{~km})$, and $\alpha=1.0(2160 \mathrm{~km})$ were used (see Fig. 4). All these runs were done with background mixing ratios of $\mathrm{O}_{3}=20 \mathrm{nmol} \mathrm{mol}^{-1}$ and $\mathrm{NO}_{\mathrm{x}}=20 \mathrm{pmol} \mathrm{mol}^{-1}$.

In the case of $\alpha=1.0$ mixing is very quick and 1 day after plume emission background and plume air cannot be distinguished anymore.

For $\alpha=0.62$ the opposite is the case, mixing is very slow and in most species differences between background and plume air are visible on the third day after plume release. The conversion of $\mathrm{O}_{3}$ to $\mathrm{NO}_{2}$ on the first day after plume release is very strong (note that $\left[\mathrm{O}_{\mathrm{x}}\right]$ remains constant during this conversion), and strong $\mathrm{O}_{\mathrm{x}}$ production is still occuring on the second day after plume release.

The maximum $\mathrm{OH}$ concentrations in the plume are $6 \times 10^{6}$ molec $\mathrm{cm}^{-3}$ for the run with $\alpha=0.62$ and about $9 \times 10^{6}$ molec $\mathrm{cm}^{-3}$ for the run with $\alpha$ values between 0.75 and 1 . The maximum $\left[\mathrm{HNO}_{3}\right]$ are $170 \mathrm{pmol} \mathrm{mol}^{-1}$ for the run with $\alpha=0.62,80 \mathrm{pmol} \mathrm{mol}^{-1}$ for the run with $\alpha=0.75,25$ pmol mol ${ }^{-1}$ for the run with $\alpha=0.87$ and $15 \mathrm{pmol} \mathrm{mol}^{-1}$ for the run with $\alpha=1$.

The results from the runs with $\alpha=0.62$ are unrealistic because such a strong and persistent separation between plume and background air is not expected to occur in the MBL. On the other hand, the very strong mixing in the runs with $\alpha>0.82$ is not consistent with the observed persistence of ship tracks and probably only valid for extremely turbulent cases, so that our "best guess" of the $\alpha$ is likely appropriate.

The strongest mixing occurs in the first 5 to $6 \mathrm{~h}$ after emission of the plume. After this time the volume of the plume is already quite large, so that the entrainment of background air becomes a rather slow process. By this time, the term $\alpha / t$, which determines the strength of the mixing (see Eq. 5) is of 

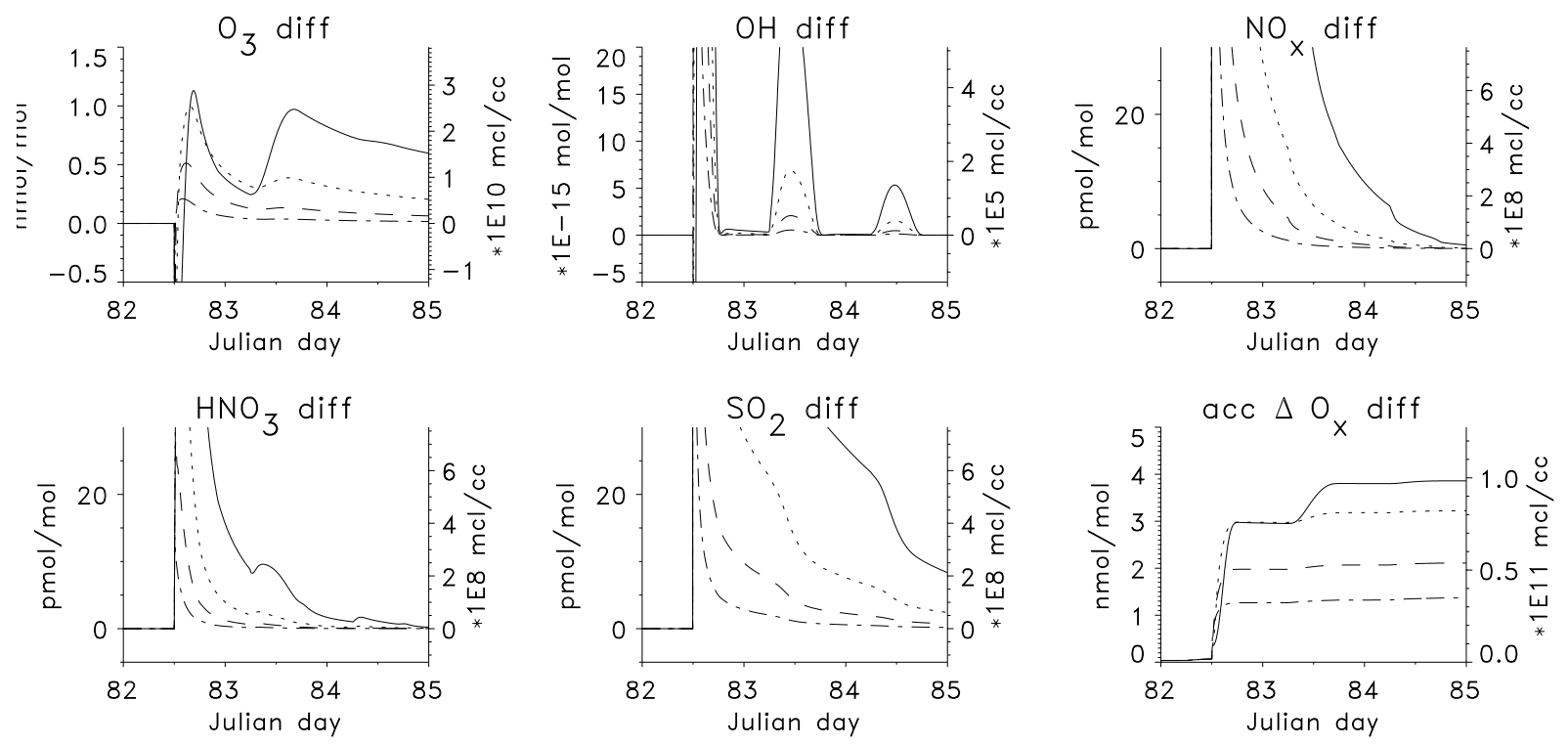

Fig. 4. Same as Figure 3, but for runs with different plume expansion rates: solid line: $\alpha=0.62$, dotted: $\alpha=0.75$ ("best guess"), dashed: $\alpha=0.87$, dash-dotted: $\alpha=1$. For these runs the initial $\mathrm{O}_{3}$ mixing ratio is $20 \mathrm{nmol} \mathrm{mol}^{-1}$, that of $\mathrm{SO}_{2}$ is $90 \mathrm{pmol} \mathrm{mol}^{-1}$ and that of $\mathrm{NO}_{\mathrm{x}}$ is $20 \mathrm{pmol} \mathrm{mol}^{-1}$.

the order of $10^{-5}$, so then mixing is only relevant for species with very large gradients between plume and background air.

A consequence of this is that processes that sustain high concentrations of the pollutants in the first hours of plume evolution lead to higher levels of pollutants in the plume later on. The height of the MBL defines the maximum height to which the pollutants can rise without extra buoyancy, because the inversion at the top of the MBL provides a barrier for the vertical transport of pollutants. A shallow MBL means that the pollutants are confined to a smaller volume of air and therefore the concentrations are higher. As relative changes in concentrations due to entrainment of background air are strongest in the first hours after plume release, a shallower MBL has the same net effect as small values of $\alpha$ for the horizontal mixing although the magnitude of the changes due to different MBL heights is smaller (not shown).

Diurnal variations in the height of the MBL might lead to the export of pollution into the free troposphere, where the potential for long-range transport of reservoir species exists. This process might also lead to faster loss of $\mathrm{NO}_{\mathrm{x}}$ from the MBL. This would need to be to be addressed with a highly resolved 3D model (LES model).

\subsection{Effects of aerosol chemistry}

To study the effects of aerosol chemistry on the evolution of the ship plume we did runs with background aerosol only; with the additional emission of partly soluble particles (the soluble part is assumed to be $\mathrm{H}_{2} \mathrm{SO}_{4}$ ); with the additional emission of both partly soluble particles and insoluble soot
Table 3. Description of the different runs including aerosols

\begin{tabular}{lll}
\hline case & partly soluble particles & soot particles \\
\hline run 2 & $1.82 \times 10^{7} \mathrm{~cm}^{-3}$ & none \\
run 3 & $1.82 \times 10^{8} \mathrm{~cm}^{-3}$ & none \\
run 4 & $1.82 \times 10^{7} \mathrm{~cm}^{-3}$ & $1 . \times 10^{5} \mathrm{~cm}^{-3}$ \\
run 5 & $1.82 \times 10^{7} \mathrm{~cm}^{-3}$ & $1 . \times 10^{7} \mathrm{~cm}^{-3}$ \\
run 6 & $1.82 \times 10^{8} \mathrm{~cm}^{-3}$ & $1 . \times 10^{7} \mathrm{~cm}^{-3}$ \\
\hline
\end{tabular}

particles from the ship (= base run); and without inclusion of aerosols.

The runs were made for an initial $\mathrm{O}_{3}$ mixing ratio of 20 $\mathrm{nmol} \mathrm{mol}{ }^{-1}$ and initial $\mathrm{NO}_{\mathrm{x}}$ mixing ratio of $20 \mathrm{pmol} \mathrm{mol}^{-1}$.

Run 0 is with gas phase chemistry only and run 1 with background aerosols only. The total surface areas for the background sulfate and sea salt particles are $1.75 \times 10^{-5}$ $\mathrm{m}^{2} \mathrm{~m}^{-3}$ and $3.38 \times 10^{-5} \mathrm{~m}^{2} \mathrm{~m}^{-3}$, respectively. We compare these runs and runs with the concentrations of ship-derived particles one second after plume release as listed in Table 3.

The initial surface areas of partly soluble ship particles are $0.568 \mathrm{~m}^{2} \mathrm{~m}^{-3}$ and $5.68 \mathrm{~m}^{2} \mathrm{~m}^{-3}$ for the low and high estimates, respectively, whereas they are $2.6 \times 10^{-3} \mathrm{~m}^{2} \mathrm{~m}^{-3}$ and $0.26 \mathrm{~m}^{2} \mathrm{~m}^{-3}$ for the soot particles, respectively.

Due to dilution, the concentration of the ship derived particles decreases by more than 2 orders of magnitude in the first $2 \mathrm{~min}$. After $1 \mathrm{~h}$ the concentration decreased by about 4 orders of magnitude. This illustrates why the emission rates of particles have to be very high, in order to keep the number 

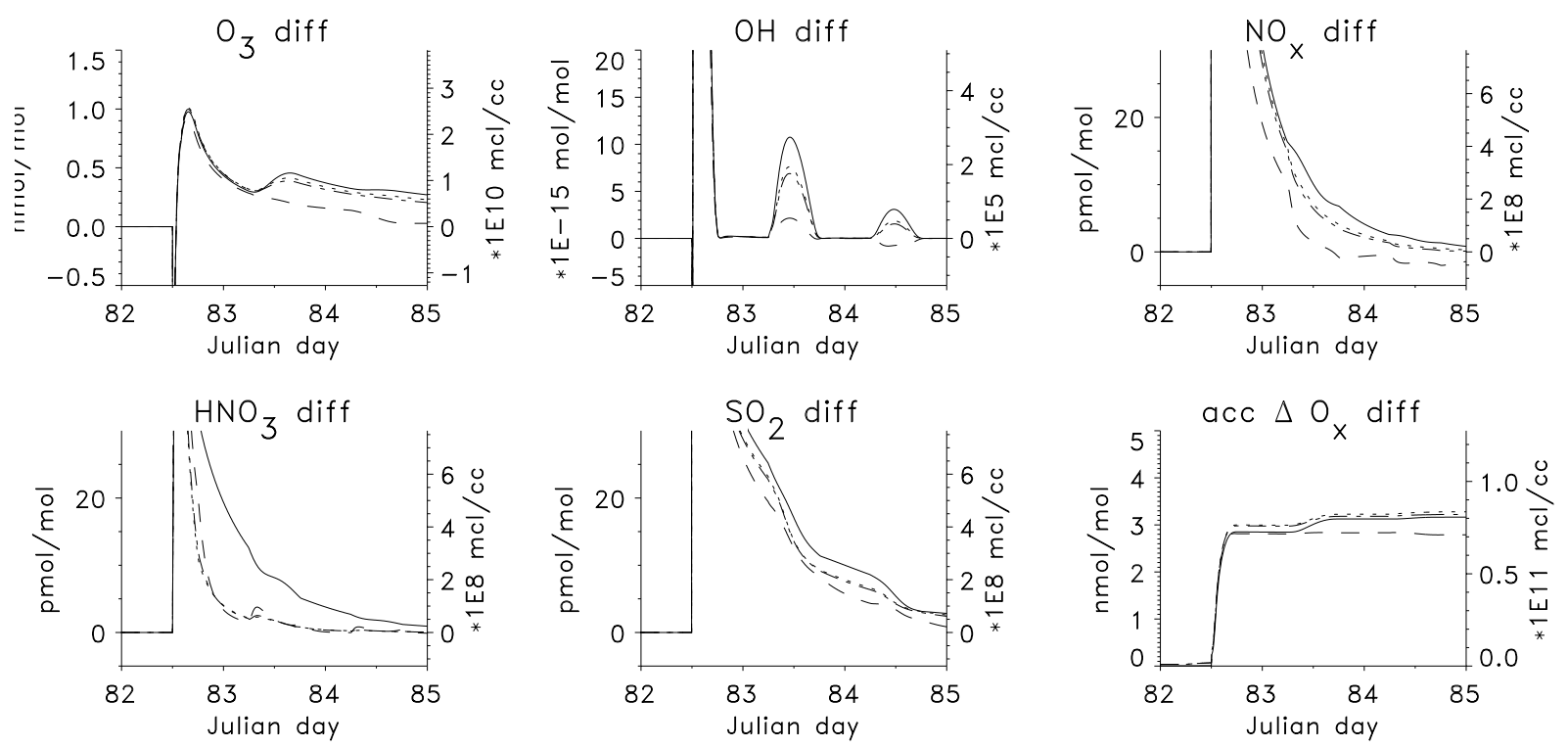

Fig. 5. Same as Fig. 3, but for runs including aerosol chemistry: solid line: no aerosol chemistry (run 0); dotted: background aerosol only (run 1); dashed: additionally partly soluble ship particles, concentration 1 second after plume release: $1.82 \times 10^{8} \mathrm{~cm}^{-3}$ (run 3 ); dash-dotted: additionally partly soluble ship particles $\left(1.82 \times 10^{7} \mathrm{~cm}^{-3}\right)$ and soot particles (run $4=$ base run). For all runs the initial $\mathrm{NO}_{\mathrm{x}}$ was 20

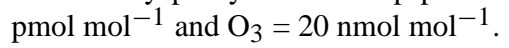

of ship derived particles comparable to the number of background particles for a time span that is long enough to ensure that heterogeneous reactions can show an effect. For run 2 the number of ship derived particles equals the number of background particles after about $4.4 \mathrm{~h}$. For run 3 this is the case after 2.37 days.

The overall qualitative evolution of the gas phase species in the plume air in runs 1 to 6 is similar to the base run that has been discussed previously. The differences between runs 2,4 , and 5 are negligible as are the differences between runs 3 and 6. This means that the effect of soot aerosol on the evolution of the gas phase chemistry is negligible. Even the very high soot concentrations in runs 5 and 6 did not show any importance of the soot aerosol. This can be understood by looking at the rate coefficients and associated lifetimes. The highest accommodation coefficient was assumed for $\mathrm{HO}_{2}$, with $\alpha_{\mathrm{HO}_{2}}=10^{-2}$. In the first second after plume emission the lifetime of $\mathrm{HO}_{2}$ against uptake on soot is $\tau_{\text {soot }}=357 \mathrm{~s}$ for a soot concentration of $1 \times 10^{5} \mathrm{~cm}^{-3}$ after 1 second. Two minutes after plume release the lifetime increased to $\tau_{\text {soot }}=0.86$ days already. The lifetime of $\mathrm{HO}_{2}$ against reaction with $\mathrm{NO}$ at an NO mixing ratio of 1 nmol mol${ }^{-1}$ is about $\tau_{\mathrm{NO}_{2}}=4.8 \mathrm{~s}$ (at $290 \mathrm{~K}$, DeMore et al., 1997). In the early plume stages the NO concentration is a lot higher than this value. This indicates that even with our upper limit estimates of reaction rates, soot aerosol in the ship plume has no effect on gas phase chemistry.

In Fig. 5 we compare runs $0,1,3$, and 4 . The overall effects of aerosol particles on the chemistry in a ship plume in the cloud-free MBL are important for some species accord- ing to the model. In run 3 the chemical lifetime of the ship plume is reduced substantially, which can easily be seen, e.g. in the small $\mathrm{OH}$ and $\mathrm{NO}_{\mathrm{x}}$ differences between plume and background air. As in the runs with high initial $\mathrm{NO}_{\mathrm{x}}$ mixing ratios loss of $\mathrm{NO}_{\mathrm{y}}$ on ship derived sulfate particles leads to smaller $\mathrm{NO}_{\mathrm{x}}$ mixing ratios in run 3 than in the background. The decline in $\mathrm{HNO}_{3}$ is similar for all runs with aerosols because it is mainly taken up by sea salt aerosol.

$\mathrm{SO}_{2}$ evolves similarly in all runs including the gas phase only run. This indicates that its main sink in the plume is dilution and not uptake on the particles, which is confirmed by a lifetime of the order of $30 \mathrm{~h}$, at $[\mathrm{OH}]=1$ $\times 10^{7} \mathrm{molec}^{-3}$, (DeMore et al., 1997). Its oxidation product $\mathrm{H}_{2} \mathrm{SO}_{4}$ is taken up by the particles, increasing the $\mathrm{S}(\mathrm{VI})$ content of the aerosols by a few pmol mol${ }^{-1}$ ( 3 to $10 \%$ for the background aerosols).

In the runs with the emission of very high numbers of ship derived particles (runs 3 and 6), there is enough surface available to convert $\mathrm{BrNO}_{3}$ and $\mathrm{HBr}$ to more reactive bromine species. Therefore in these runs no drop in $\mathrm{Br}_{\mathrm{x}}$ occurs after plume release (not shown).

In summary, the emission of soot particles from ships with the characteristica that we assumed is unimportant for the chemistry of the cloud-free MBL and only very high particle emission rates of partly soluble particles as in run 3 lead to disturbances of the chemistry that are distinguishable from the effect of background aerosol particles.

von Glasow (2000) presents a preliminary study of the chemical effects of ship emissions into a MBL that is capped with stratiform clouds. This one-dimensional model uses a 
similar plume expansion approach as described here. The results show a strong influence of the state of coupling between cloud and sub-cloud layers. If these layers are coupled, the soluble gases that are emitted are rapidly scavenged. If cloud and sub-cloud layers are decoupled then the emissions are confined to a rather small region leading to higher mixing ratios of pollutants (and $\mathrm{Cl}_{2}$ and $\mathrm{HCl}$ ) than in a cloud-free case. Upon coupling of the cloud and sub-cloud layers these differences disppeared quickly. An obvious conclusion from this study was that the lifetimes of soluble pollutants (e.g. $\mathrm{SO}_{2}$ ) are reduced in a cloudy MBL, whereas those of insoluble pollutants are roughly the same as in cloud-free cases. Furthermore differences in aqueous phase chemistry due to the emission of soluble particles and sulfur compounds can be expected. Based on these results, our box model calculations that were performed for the cloud-free MBL provide an upper limit of the effects in the atmosphere.

\subsection{Emission strength and $\mathrm{NO}_{\mathrm{x}}$ partitioning}

We did further sensitivity studies where we varied the ship emissions by a factor of 0.1 and 10 , respectively. In the case of a reduced emission strength, the chemical plume lifetime was reduced to about $12 \mathrm{~h}$, whereas it was longer than 3 days if the emission strength was increased.

EPA (2000) gave a NO: $\mathrm{NO}_{2}$ ratio for the exhaust air of 96:4. We tested the implications of a higher fraction of $\mathrm{NO}_{2}$ in the plume air. As expected, a higher $\mathrm{NO}_{2}$ fraction leads to $\mathrm{O}_{3}$ formation by photolysis of $\mathrm{NO}_{2}$. This effect is, however, important only in the first $100 \mathrm{~s}$ after plume release and of no importance for the later evolution of plume air. After this time the $\mathrm{O}_{3}$ that was derived from $\mathrm{NO}_{2}$ photolysis is diluted by entrainment of background air and the $\mathrm{NO}: \mathrm{NO}_{2}$ ratio is about 0.8 for our base case as well as for $\mathrm{NO}: \mathrm{NO}_{2}$ emission ratios of 20:80, 50:50 and 80:20. If the emission occurs during night, the $\mathrm{NO}: \mathrm{NO}_{2}$ emission ratio is of no importance, as all $\mathrm{NO}$ reacts very quickly to $\mathrm{NO}_{2}$.

\section{Effects of emissions of several ships and of plume overlap}

So far the emissions of only one ship have been considered. To be able to extrapolate these results to a more global picture, the effects of the emissions of several ships have to be discussed. In Sect. 4.1 we explore the plume overlap in the framework of our model and compare our results in Sect. 4.2 with the approach used in global models. It has to be emphasized that our extrapolation method is only one of several possibilities.

\subsection{Upscaling approach}

From the emissions inventory of Corbett et al. (1999) annual mean emission fluxes (mass nitrogen, sulfur) per area and time can be extracted. If the emissions rate of one ship is known, the number of ships per area that are needed to produce the emissions as they are listed in the inventory, can be calculated. For the most frequently crossed ocean regions (North Atlantic and North Pacific) values from Corbett et al. (1999) are about $10^{-9} \mathrm{~g}(\mathrm{~N}) \mathrm{m}^{-2} \mathrm{~s}^{-1}$ for a fleet that emits on average $22.7 \mathrm{~g}(\mathrm{~N}) \mathrm{kg}_{\text {fuel }}^{-1}$. Hobbs et al. (2000) give a mean fuel consumption of $0.84 \mathrm{~kg}_{\text {fuel s}} \mathrm{s}^{-1}$ (median $=0.69$ $\mathrm{kg}_{\text {fuel }} \mathrm{s}^{-1}$ ) for ships studied during the MAST campaign. They estimated the fuel consumption from the nominal engine power as listed in ship registries and the observed ship speed. Fuel consumption rates can also be estimated from EPA (2000), that give an average fuel consumption of 223 $\mathrm{g}_{\text {fuel }} \mathrm{kWh}^{-1}$. Assuming an engine power of $16 \mathrm{MW}$, which is the average of the engine power during MAST (median = 13.4 MW), this would result in a fuel consumption of 0.993 $\mathrm{kg}_{\text {fuel }} \mathrm{s}^{-1}$, similar to the estimate from Hobbs et al. (2000).

For the further discussion we make use of emissions by an "average ship" based on previously listed mean values which are higher than the medians. According to Corbett et al. (1999) $42 \%$ of the ships cause $70 \%$ of the total annual nitrogen emissions. Clearly, the global fleet of ships consists of small and large ships with different emissions characteristics. It would be best to take this into account which, however, cannot be done in the type of study that we did.

Based on these data an "average ship" emits $19.1 \mathrm{~g}(\mathrm{~N}) \mathrm{s}^{-1}$. This leads to $5.24 \times 10^{-11}$ ships $\mathrm{m}^{-2}$ that have to be present all year round in the more frequently crossed regions to produce the emissions that were estimated by Corbett et al. (1999). Taking the uncertainty of this estimate into account, sensitivity studies are made using values from 1 to $10 \times 10^{-11}$ ships $\mathrm{m}^{-2}$.

To estimate the impact of several ships in an area of a certain size the following assumptions are made: i) All ships are homogeneously distributed over this area because the ocean regions considered are quite large and different destinations lead to different ship routes. ii) As most traffic in the more frequently traveled oceans crosses these regions from Asia to North America and from North America to Europe (or in the opposite direction) all routes are parallel.

For convenience the following calculations are based on the emissions of ships in a certain area. The size of this "cell" is determined by the distance that a ship travels during the chemical lifetime of its plume. During these 2 days a ship that has a speed of $10 \mathrm{~m} \mathrm{~s}^{-1}$ travels $1730 \mathrm{~km}$. We use this as length of a cell which, for convenience, we chose to be quadratic. In the chosen cell area of $1730 \mathrm{~km}$ by $1730 \mathrm{~km}$ between about 30 to 300 ships are cruising at any point in time based on the "ship density" given above. Two days after plume emission the plume width is $w_{p l}=85 \mathrm{~km}$ using $\alpha=$ 0.75 (see Eq. 1). Therefore the area that is influenced by one ship in 2 days is about $7.4 \times 10^{10} \mathrm{~m}^{2}$ (approximately $0.5 \times$ $85 \mathrm{~km} \times 1730 \mathrm{~km}$ ) or $2.5 \%$ of the cell area. When more than 40 ships are present in the cell area, overlap of the plumes has to occur, i.e. ships emit their exhaust in air that has been 
Table 4. Extrapolation of different scenarios.

\begin{tabular}{|c|c|c|c|c|c|}
\hline case & $\mathrm{O}_{3}$ & $\mathrm{OH}$ & $\mathrm{NO}_{\mathrm{x}}$ & $\mathrm{HNO}_{3}$ & $\mathrm{SO}_{2}$ \\
\hline & {$\left[\mathrm{nmol} \mathrm{mol}^{-1}\right]$} & {$\left[\right.$ molec $\left.\mathrm{cm}^{-3}\right]$} & {$\left[\mathrm{pmol} \mathrm{mol}{ }^{-1}\right]$} & {$\left[\mathrm{pmol} \mathrm{mol}^{-1}\right]$} & {$\left[\mathrm{pmol} \mathrm{mol}^{-1}\right]$} \\
\hline background & 22.5 & $5.8 \times 10^{5}$ & 10.9 & 1.9 & 89.6 \\
\hline 30 ships, clean & 22.5 & $5.9 \times 10^{5}$ & 11.4 & 1.9 & 89.7 \\
\hline 100 ships, clean & 22.5 & $5.9 \times 10^{5}$ & 12.5 & 2.0 & 90.2 \\
\hline 300 ships, clean & 22.5 & $5.9 \times 10^{5}$ & 15.6 & 2.1 & 91.5 \\
\hline 30 ships, poll & 23.3 & $6.3 \times 10^{5}$ & 14.2 & 2.5 & 98.8 \\
\hline 100 ships, poll & 25.9 & $7.0 \times 10^{5}$ & 17.4 & 3.9 & 117.6 \\
\hline 300 ships, poll & 36.2 & $11.7 \times 10^{5}$ & 58.1 & 34.5 & 254.1 \\
\hline 100 ships, poll, short ${ }^{a}$ & 23.9 & $6.4 \times 10^{5}$ & 15.2 & 2.8 & 103.5 \\
\hline cont. gas $b$ & 44.6 & $16.2 \times 10^{5}$ & 109.2 & 88.6 & 263.2 \\
\hline cont. aerosol $b$ & 39.6 & $14.0 \times 10^{5}$ & 89.0 & 21.2 & 253.5 \\
\hline
\end{tabular}

Mean mixing ratios in a cell of $1730 \mathrm{~km}$ by $1730 \mathrm{~km}$. 30 ships in this area correspond to an emission of $2.7 \times 10^{-10} \mathrm{~g}(\mathrm{~N}) \mathrm{m}^{-2} \mathrm{~s}-1,100$ ships correspond to $1 \times 10^{-9} \mathrm{~g}(\mathrm{~N}) \mathrm{m}^{-2} \mathrm{~s}^{-1}$ and 300 ships to $2.7 \times 10^{-9} \mathrm{~g}(\mathrm{~N}) \mathrm{m}^{-2} \mathrm{~s}^{-1}$, respectively. In the "clean" cases background air is mixed into the plume, whereas in the "poll" cases air that has been influenced by a previous ship is mixed into the plume. For a description of the "poll" cases see text. In the "background" case no ship emissions are considered. Plume lifetime for these runs was 2 days.

${ }^{a}$ Run with a chemical plume lifetime of 1 day $(\alpha=0.87, \beta=0.65)$. The area of the cell used for averaging was adjusted.

${ }^{b}$ Steady state values from the runs discussed in Sect. 4.2. Using a similar scaling approach as for the data in Table 2 emissions for CO were estimated to be $4 \times 10^{8}$ molec $\mathrm{cm}^{-2} \mathrm{~s}^{-1}$ and $2 \times 10^{7}$ molec $\mathrm{cm}^{-2} \mathrm{~s}^{-1}$ for HCHO.

polluted by previous ships.

Based on these estimates, we discuss seven mixing scenarios: low, best guess and high emission rates (i.e. 30, 100 and 300 ships per cell of $1730 \mathrm{~km}$ by $1730 \mathrm{~km}$ ), each case with plume emission in background air and air that had been influenced by previous ships, and one with 100 ships, emission in prepolluted air, but with a reduced plume lifetime.

For the runs in pre-polluted air we assume that after emission of a first plume no background air but only air that had been influenced by a previous plume is entrained. The time lag between plume emissions is calculated based on the number of ship plumes that overlap in the different cases. In the best guess ("100 poll") scenario 2.5 plumes overlap, therefore the time lag, based on a chemical lifetime of the plume of 2 days is about $19 \mathrm{~h}$. This results in increasing pollution levels in both the "plume" and "background" air masses that we consider in our box model (see Sect. 2) and after a few days steady state mixing ratios are established. Note that this approach differs from the one used in von Glasow et al. (2002a). We have to stress that these results are based on assumptions that involve substantial uncertainties, especially the plume dispersion will be different in specific ship plumes. Our upscaling results are not supposed to give final answers, they are more pointing to research needs and to give an idea of effects on a global scale. The use of box models for upscaling can only give first ideas, it cannot replace further studies with high-resultion 3D models (i.e. LES models).

Table 4 shows the resulting mean mixing ratios for runs with ("poll") and without ("clean") overlap of ship plumes. The "30 ships, clean" case which corresponds to an emis- sion flux of $1.9 \times 10^{-10} \mathrm{~g}(\mathrm{~N}) \mathrm{m}^{-2} \mathrm{~s}^{-1}$ can be seen as most relevant for less heavily traveled regions and the " 100 ships, poll" case which corresponds to an emission flux of $6.4 \times 10^{-10} \mathrm{~g}(\mathrm{~N}) \mathrm{m}^{-2} \mathrm{~s}^{-1}$ as most relevant for the North Atlantic and North Pacific. For coastal regions the "300 ships, poll" case might apply (emission flux of $1.9 \times 10^{-9}$ $\left.\mathrm{g}(\mathrm{N}) \mathrm{m}^{-2} \mathrm{~s}^{-1}\right)$. According to these results the lower limit scenario with emissions into background air ("30 ships, clean") would be nearly indistinguishable from the background air. The high emission scenario with entrainment of clean background air ("300 ships, clean") would increase $\mathrm{OH}$ by $2 \%, \mathrm{NO}_{\mathrm{x}}$ by $43 \%$ and $\mathrm{SO}_{2}$ by $2 \%$ compared to a case without ship emissions.

The effects of emission into prepolluted air are more apparent, especially for the upper limit scenario ("300 ships, poll"). Here $\mathrm{O}_{3}$ is predicted to increase by $60 \%$ compared to background air, $\mathrm{OH}$ would increase by $100 \%$. $\mathrm{NO}_{\mathrm{x}}$ would increase by a factor of 5.3 and $\mathrm{SO}_{2}$ by $187 \%$. In the best guess scenario ("100 ships, poll"), $\mathrm{O}_{3}$ would increase by $15 \%, \mathrm{OH}$ by $21 \%, \mathrm{NO}_{\mathrm{x}}$ by $60 \%$ and $\mathrm{SO}_{2}$ by $31 \%$.

The run with enhanced entrainment of air into the plume ("100 ships, poll, short", for conditions in the North Atlantic and North Pacific) shows a decrease of the effect of ship emissions with the overall effects being close to the lower limit scenario ("30 ships, poll”).

\subsection{Comparison with the approach used in global models}

Kasibhatla et al. (2000) and Davis et al. (2001) suggested that the impact of ship emissions on $\mathrm{NO}_{\mathrm{x}}$ concentrations in the 
MBL might by overestimated by global models compared to measurements. To check this we performed additional runs (with and without aerosol chemistry) with our box model. These runs include the chemistry that we described earlier but no plume expansion is considered. Instead ship emissions are treated as in a global chemistry transport model by assuming a continuous source of the ship pollutants. The emission fluxes are the same as in the best guess scencario ("100 ships" case).

These runs show significant production of $\mathrm{O}_{\mathrm{x}}$. The steady state mixing ratios for $\mathrm{O}_{3}$ are about 40 and $45 \mathrm{nmol} \mathrm{mol}^{-1}$ (including a continuous source as in the other runs) for the runs with and without background aerosol chemistry, respectively, compared to 25 and $29 \mathrm{nmol} \mathrm{mol}^{-1}$ for the same runs without ship emissions. The mixing ratios of $\mathrm{OH}$ are more than doubled.

$\mathrm{NO}_{\mathrm{x}}$ levels increased to $110 \mathrm{pmol} \mathrm{mol}^{-1}$ in the run without aerosol chemistry and to $90 \mathrm{pmol} \mathrm{mol}^{-1}$ in the run including aerosol chemistry compared to $10 \mathrm{pmol} \mathrm{mol}^{-1}$ in the background and $46 \mathrm{pmol} \mathrm{mol}^{-1}$ in the best guess scenario with plume overlap ("100 ships, poll"). The difference in steady state between these 2 runs of about $20 \mathrm{pmol} \mathrm{mol}^{-1}$ implies an additional sink of roughly $20 \mathrm{pmol} \mathrm{mol}^{-1} \mathrm{day}^{-1}$ in the run including aerosol chemistry. The heterogeneous reactions responsible for this difference are uptake of $\mathrm{NO}_{3}, \mathrm{~N}_{2} \mathrm{O}_{5}$, and $\mathrm{XNO}_{3}(\mathrm{X}=\mathrm{Cl}, \mathrm{Br})$ on the aerosol. In the model the most important path is uptake of $\mathrm{BrNO}_{3}$ on the sulfate aerosol accounting for roughly two-thirds of the total loss of $\mathrm{NO}_{\mathrm{x}}$.

The results for $\mathrm{NO}_{\mathrm{x}}, \mathrm{OH}$ and $\mathrm{O}_{3}$ from these runs (see Table 4) are similar to but somewhat smaller than the numbers from global models (Lawrence and Crutzen, 1999; Kasibhatla et al., 2000). Chemistry on aerosol particles appears to explain only part of the great differences between measurements of $\mathrm{NO}_{\mathrm{x}}$ in the MBL and global model results.

Comparing the results with constant emissions with the steady state concentrations as discussed in the previous section ("cont, aerosol" vs. "100 ships, poll"), differences of about a factor of 5 in $\mathrm{HNO}_{3}$ and $\mathrm{NO}_{\mathrm{x}}$ and a factor of 2 in $\mathrm{OH}$ and $\mathrm{SO}_{2}$ are apparent. As already mentioned at the end of Sect. 2.1, the dilution of plume air does not affect the mass balance of the emitted species because dilution in the model is only by entrainment of background air and not by detrainment of plume air.

As suggested by Dentener (2002) we made a consistency check of our extrapolations by decreasing the emissions per ship and increasing at the same time the number of ships thereby approaching the "constant emissions" approach of global models. In our upscaling runs it is implicitly assumed that for plume dilution only the last preceding plume is of importance and that for that plume dilution and/or entrainment is not important at all. If ship emissions are assumed to occur very frequently (i.e. order of an hour or less apart) this assumption is not correct any more. As stated in Sect. 3.4 the "rapid mixing time" ends after about $6 \mathrm{~h}$ and if emissions are reduced such that ship frequency is still more than $6 \mathrm{~h}$, the proposed consistency test (distribution of the emissions to 3 times more ships) shows a convergence of the " 100 ships, poll" run towards "cont, aerosol". It fails, however, for an increase of the number of ships by a factor of 10 or 30, because then the time between plume emissions is on the order of or shorter than 1 hour and the implicit-dilution assumption is not valid anymore. Furthermore, a reduction in plume emission strength also leads to a reduction of plume lifetime. This has to be accounted for in the calculation of time lag between ships which on the other hand implies that it would not be as strict of a consistency test as could be hoped.

As suggested by Davis et al. (2001) for differences between measurements and global model results, the differences between our upscaling approach and our runs with constant emissions are related to the extremely high $\mathrm{NO}_{\mathrm{x}}$ mixing ratios and very rapid dilution in plume air compared to constantly high $\mathrm{NO}_{\mathrm{x}}$ values in the air affected by a continuous source. The differences are a result of different lifetimes of $\mathrm{NO}_{\mathrm{x}}$ in air with high $\mathrm{NO}_{\mathrm{x}}$ and $\mathrm{OH}$ concentrations (plume air) and in air with moderate increases in these 2 species (continuous emissions).

The lifetime of $\mathrm{NO}_{\mathrm{x}}$ in the early stages of the plume is strongly reduced compared to background situations. Peak concentrations of $\mathrm{OH}$ in the plume are about $\mathrm{OH}=1.1 \times 10^{7}$ molec $\mathrm{cm}^{-3}$. Using a rate coefficient of $k=9.1 \times$ $10^{-12} \mathrm{~cm}^{3}$ molec $^{-1} \mathrm{~s}^{-1}$ (Sander et al. (2000) at $p=1013.25$ $\mathrm{hPa}, T=298 \mathrm{~K}$ ), the $\mathrm{NO}_{\mathrm{x}}$ e-folding lifetime due to the reaction $\mathrm{NO}_{2}+\mathrm{OH} \longrightarrow \mathrm{HNO}_{3}$ would be about $2.76 \mathrm{~h}$ compared to $14.7 \mathrm{~h}$ in the background air (based on an $\mathrm{OH}$ concentration of about $2 \times 10^{6}$ molec $\mathrm{cm}^{-3}$ ). As the concentrations of $\mathrm{OH}$ and all other species decrease rapidly in the first hours after plume emission, we calculated the following mean e-folding lifetimes ("mean lifetime") for our base run with plume dilution. The mean lifetime of $\mathrm{NO}_{\mathrm{x}}$ in the first $6 \mathrm{~h}$ after emission of a plume at 12:00 is about $7.5 \mathrm{~h}$ in plume air compared to $26.9 \mathrm{~h}$ in undisturbed air, i.e. $\mathrm{NO}_{\mathrm{x}}$ is lost 3.6 times as fast as in the background air.

The mean lifetime of $\mathrm{NO}_{\mathrm{x}}$ in the runs with continuous emissions between 12:00 and 18:00 (i.e. the same time span as given above) is $12.7 \mathrm{~h}$, i.e. 1.7 times longer than in the run with description of plume chemistry. During the time of highest $\mathrm{OH}$ concentrations $\left(5 \times 10^{6}\right.$ molec $\left.\mathrm{cm}^{-3}\right)$ the efolding lifetime of $\mathrm{NO}_{\mathrm{x}}$ is about $6.1 \mathrm{~h}$, i.e. it is more than 2 times faster in the plume case. As $\mathrm{NO}_{\mathrm{x}}$ loss is strongest in the first hours after plume emission, the large differences in $\mathrm{NO}_{\mathrm{x}}$ lifetime during this period are the main reason for the differences between the two discussed emission scenarios (plume vs. continuous emissions). From these estimates it is obvious that the incorporation of the plume evolution is critical in assessing the effects of ship emissions.

Our results provide a first quantification of the conclusion of Davis et al. (2001) that reduced $\mathrm{NO}_{\mathrm{x}}$ lifetime in the ship plume plays a role in clean maritime regions and additionally show that the loss due to aerosol reactions contribute a further $20 \%$ to reducing $\mathrm{NO}_{\mathrm{x}}$ in the plume. The recent study by 
Song et al. (2002) uses a Gaussian plume dilution approach and finds similar effects on $\mathrm{NO}_{\mathrm{x}}$ lifetime as we do.

We want to add, that in the interpretation of field $\mathrm{NO}_{\mathrm{x}}$ data care has to be taken. From our studies it appears likely that only fresh plumes have $\mathrm{NO}_{\mathrm{x}}$ levels that are significantly elevated above background values, before it is converted to e.g. $\mathrm{HNO}_{3}$ and/or deposited. If these " $\mathrm{NO}_{\mathrm{x}}$-spikes" are filtered during processing of the data, important information is lost. This it is important to look for the variability of $\mathrm{NO}_{\mathrm{x}}$, and also of $\mathrm{HNO}_{3}$, in the data, similar to the use of medians in Kasibhatla et al. (2000) and Davis et al. (2001), to get information about the impact of ship emissions on the chemistry of the MBL.

Therefore there is clearly a need for more data on global ship emissions, for measurements over the more heavily traversed ocean regions and for more information on additional chemical reactions that might occur in plume air.

In coastal regions or, e.g. in the oceans off Asia, where ship emissions are estimated to have grown by $5.9 \%$ per year between 1988 and 1995 (Streets et al., 2000) ship emissions definitely play a role for air quality, now and in the future.

\section{Uncertainties}

In the previous sections we already discussed the uncertainties of our model and upscaling approach. Another major uncertainty in this study is the estimate of the ship emissions. We mainly used the numbers from Corbett et al. (1999) that were already used in previously published studies (Lawrence and Crutzen, 1999; Kasibhatla et al., 2000; Davis et al., 2001), so intercomparison between our and these studies is facilitated. Some of the data are confirmed by the compilation of EPA (2000). Also, Streets et al. (2000) show that their estimates for $\mathrm{SO}_{2}$ emissions in Asian waters and the respective data from Corbett et al. (1999) disagree only by $13 \%$, which might be due to the fact, that Streets et al. (2000) did not consider fishing and military ships. Nevertheless, it is important to consider the uncertainties which may be present in the data of Corbett et al. (1999).

For this purpose we estimated the average deployment time (time spent at sea) of a ship based on data given by Corbett et al. (1999).

The total annual world marine fuel usage from Table 2 in Corbett et al. (1999) is approximately $1.5 \times 10^{11} \mathrm{~kg}$. According to Corbett et al. (1999) $42 \%$ of the ships cause $70 \%$ of the total annual nitrogen emissions. Based on this we assume that $42 \%$ of the ships also cause $70 \%$ of the total annual fuel consumption which leads to an average fuel usage for these ships of $2.5 \times 10^{6} \mathrm{~kg} \mathrm{ship}^{-1} \mathrm{a}^{-1}$. With a fuel consumption of roughly $1 \mathrm{~kg}$ (fuel) $\mathrm{s}^{-1}$ (EPA, 2000, see Sect. 4.1) this would mean that each ship would be operating $2.5 \times 10^{6} \mathrm{~s}$ or 29 days per year (or 17 days per year if all ships are considered). This number is by far too small. According to Corbett et al. (1999) the deployment time of commercial ships is con- siderably larger than their estimate of 50\% deployment rate of military ships.

A similar estimate can be obtained by starting from our estimate (see Sect. 4.1) of the $\mathrm{NO}_{\mathrm{x}}$ emission per ship and time of $19.1 \mathrm{~g}(\mathrm{~N})$ ship $^{-1} \mathrm{~s}^{-1}$ which results in $6 \times 10^{8}$ $\mathrm{g}(\mathrm{N}) \operatorname{ship}^{-1} \mathrm{a}^{-1}$ if it were continuously operating. Considering that $42 \%$ of the ships cause $70 \%$ of the total annual nitrogen emissions of $3 \times 10^{12} \mathrm{~g}(\mathrm{~N}) \mathrm{a}^{-1}$ (Corbett et al., 1999), these numbers combined would give a deployment time of approximately 30 days per year (or 18 days per year if all ships are considered), very similar to the estimate above (note that these estimates are only partially independent since the the total annual nitrogen emissions of $3 \times 10^{12} \mathrm{~g}(\mathrm{~N}) \mathrm{a}^{-1}$ in Corbett et al. (1999) start from the total fuel usage of $\left.1.5 \times 10^{11} \mathrm{~kg} \mathrm{a}^{-1}\right)$.

The values of the nitrogen emission per ship and time calculated from measurements during the MAST campaign (Hobbs et al., 2000) are lower than the estimates from Corbett et al. (1999). They found values between 8.4 and $14 \mathrm{~g}(\mathrm{~N}) \mathrm{kg}(\mathrm{fuel})^{-1}$ (note that the range of this value is given incorrectly in the abstract and the text of their paper, while their Table $3\left(\mathrm{NO}_{\mathrm{x}}\right.$ in mole $\left.(\mathrm{N}) \mathrm{kg}^{-1}\right)$ gives the correct numbers (T. Garret, pers. comm. 2001, erratum accepted by J. Atmos. Sci.). The reason why these numbers are smaller than the other values from the literature (Corbett et al., 1999; EPA, 2000) is not yet resolved. Using them for the estimate of ship deployment rates would lead to deployment times of 41 to 68 days per year, which is still far too small. The data from EPA (2000), on the other hand, give an emissions rate of $22 \mathrm{~g}(\mathrm{~N}) \mathrm{s}^{-1}$ (for a ship's engine with $16 \mathrm{MW}$ cruising at $80 \%$ load), which is similar to the number we calculated from Corbett et al. (1999).

Taking the above listed arguments together one could conclude that either the emissions and fuel usage per ship or the number of active ships that were used in all cited studies (incuding this one) are too high. If the total number of registered ships and the other parameters are correct, this would imply that a much smaller fraction than $42 \%$ of these is actually active.

There is certainly still a great need for more data on the emissions of ships.

Another important uncertainty is our approach of plume dilution by entrainment of background air which is a very simple one, that does not take account of atmospheric stability or different wind shear due to different wind speed etc. As our intention was to get a global mean view of the process rather then to mimic situations that were encountered during field campaigns we think that this is justified. In future studies, however, this approach should be tested against more sophisticated models and more (until now mainly unavailable) field data. 


\section{Summary and outlook}

We studied the chemical evolution of the exhaust of ships in the MBL with a box model. Based on a simple dilution approach for the plume we found the chemical lifetime (defined as time when differences between plume and background air are reduced to $5 \%$ or less) of the ship plumes to be about 2 days. Dilution has the strongest effects during roughly the first $6 \mathrm{~h}$ after plume release. For long lived species the differences that are present after this "rapid mixing period" are conserved. Given the predicted importance of entrainment of background air, our approach should be tested in the future against more detailed models of plume dilution (e.g. large eddy simulation models) and field data. Most field measurements did not follow a ship plume over its complete lifetime, which would be important to validate model results. This was done during the ITCT $2 \mathrm{~K} 2$ campaign off California in 2002 and first results indicate very rapid dropoff in $\mathrm{NO}_{\mathrm{x}}$ and $\mathrm{NO}_{\mathrm{y}}$ after plume release which is unlikely to be explained by $\mathrm{OH}$-chemistry alone (Corbett et al., 2002).

The strongest effects of ship emissions and longest plume lifetimes were found when the emissions were into the cleanest background air. The lifetime of many species in the plume air is reduced due to high $\mathrm{OH}$ concentrations which are a consequence of the elevated $\mathrm{NO}_{\mathrm{x}}$ mixing ratios. This furthers the conclusion of Davis et al. (2001) by quantifying the effect, and in particular by showing that it is sensitive to the background conditions, being strongest for remote background regions.

We found the influence of background aerosol particles (sulfate and sea salt) to be important for the evolution of gas phase chemistry in the ship plume, whereas inclusion of soluble ship-produced aerosols was of little importance. We also used upper limits for reactions on soot aerosols and found reactions on these particles to be unimportant for ship plumes.

Chlorine is released significantly from sea salt aerosol in plume air. In our runs only minor additional (compared to the background) bromine release could occur because most bromine was already partitioned to the gas phase. In the early plume stages $\mathrm{BrO}$ reacts rapidly with $\mathrm{NO}$ thereby strongly reducing $\mathrm{BrO}$ mixing ratios but without a net effect on the $\mathrm{O}_{\mathrm{x}}$ family as $\mathrm{NO}_{2}$ is produced in this reaction. Later on, bromine is redistributed mainly towards $\mathrm{BrNO}_{3}$ in plume air.

In more frequently crossed ocean regions like the North Atlantic or North Pacific and especially in coastal regions, the plumes of several ships overlap, so we considered the overlap of ship plumes in a simplified way. We found that the reduction of $\mathrm{NO}_{\mathrm{x}}$ lifetime in the ship plume can explain part of the observed difference between open ocean $\mathrm{NO}_{\mathrm{x}}$ measurements and predictions by global models, which treat ship emissions as a constant source. According to our extrapolation (best guess scenario - " 100 ships, poll"), changes in $\mathrm{O}_{3}$ and $\mathrm{OH}$ (compared to background air) would be about 15 and $21 \%$, respectively. The mixing ratios of $\mathrm{NO}_{\mathrm{x}}, \mathrm{HNO}_{3}$ and $\mathrm{SO}_{2}$, however, would increase by $60 \%, 105 \%$, and $31 \%$, respectively. These estimates are based on background mixing ratios of $20 \mathrm{pmol} \mathrm{mol}^{-1} \mathrm{NO}_{\mathrm{x}}$ and $20 \mathrm{nmol} \mathrm{mol}^{-1} \mathrm{O}_{3}$. For cleaner regions, the effects of ships would be more pronounced. From our box model runs it is not possible to get a global perspective, so parameterizations for the plume dilution should be developed and used in global models.

It should be noted that the limitations of global models to treat point sources correctly not only apply to ship emissions but to all types of point sources, e.g. land based power plant emissions.

We have also found some inconsistencies in current fuel usage and $\mathrm{NO}_{\mathrm{x}}$ ship emissions inventories, which have to be clarified. Measurements of the chemistry and emissions directly in fresh plume air are highly encouraged to get reliable data of ship emissions and of the chemical processes at different temporal distances from the emission. This should be done at the stack and from a second platform following at variable distance downwind from the studied ship. This could be a second ship, plane or especially an airship, which is slower than a plane, highly manoeuvrable and could also make vertical profiles in the plume as was done by Frick and Hoppel (2000) to study microphysical parameters of the ship track.

Apart from uncertainties in model assumptions or emission inventories, other physical or chemical processes that were not included in our model might certainly be of importance for plume development or differences between measurements and model results.

Ship emissions are a major source of anthropogenic pollution and the input of sulfur and nitrogen to the coupled ocean-atmosphere system is a major perturbation in these areas which are usually affected only by advection of pollutants. Emissions from ships are potentially important (also for the cycle of sulfur which has not been the focus of this work) on large areas of our oceans, but especially in coastal regions. This study, among previous studies, indicates that much is left to be done. It is very important to gather more data on the emissions of ships and the chemical processes in ship plumes. In addition appropriate parametrizations for global models should be developed and further detailed studies with process models of ship plumes should be made.

Acknowledgements. We would like to thank Frank Dentener and Ulrich Pöschl for helpful comments on this paper.

\section{References}

Ackerman, A. S., Toon, O. B., and Hobbs, P. V.: Numerical modeling of ship tracks produced by injections of cloud condensation nuclei into marine stratiform clouds, J. Geophys. Res., 100, 7121-7133, 1995.

Al-Abadleh, H. and Grassian, V. H.: Heterogeneous reaction of $\mathrm{NO}_{2}$ on hexane soot: A Knudsen cell and FT-IR study, J. Phys. Chem. A, 104, 11 926-11 933, 2000. 
Ammann, M., Kalberer, M., Jost, D. T., Tobler, L., Rössler, E., Piguet, D., Gäggeler, H. W., and Baltensperger, U.: Heterogeneous production of nitrous acid on soot in polluted air masses, Nature, 395, 157-160, 1998.

Atkinson, A., Baulch, D. L., Cox, R. A., Hampson, Jr., R. F., Kerr, J. A., Rossi, M. J., and Troe, J.: Evaluated kinetic and photochemical data for atmospheric chemistry: Supplement vi, J. Phys. Chem. Ref. Data, 26, 1329-1499, 1997.

Aumont, B., Madronich, S., Ammann, M., Kalberer, M., Baltensperger, U., Hauglustaine, D., and Brocheton, F.: On the $\mathrm{NO}_{2}$ + soot reaction in the atmosphere, J. Geophys. Res., 104, 17291736, 1999.

Brühl, C. and Crutzen, P. J.: On the disproportionate role of tropospheric ozone as a filter against solar UV-B radiation, Geophys. Res. Lett., 16, 703-706, 1989.

Capaldo, K., Corbett, J. J., Kasibhatla, P., Fischbeck, P., and Pandis, S. N.: Effects of ship emissions on sulphur cycling and radiative climate forcing over the ocean, Nature, 400, 743-764, 1999.

Carlton, J. S., Danton, S. D., Gawen, R. W., Lavender, K. A., Mathieson, N. M., Newell, A. G., Reynolds, G. L., Webster, A. D., Wills, C. M. R., and Wright, A. A.: Marine Exhaust Emissions Research Programme, Lloyd's Regist. Eng. Serv., London, 1995.

Coakley, Jr., J. A., Bernstein, R. L., and Durkee, P. A.: Effect of ship-stack effluents on cloud reflectivity, Science, 237, 1020 1022, 1987

Conover, J. H.: Anomalous cloud lines, J. Atmos. Sci., 23, 778 $785,1966$.

Corbett, J. J. and Fischbeck, P.: Emissions from ships, Science, 278, 823-824, 1997.

Corbett, J. J., Fischbeck, P. S., and Pandis, S. N.: Global nitrogen and sulfur inventories for oceangoing ships, J. Geophys. Res., 104, $3457-3470,1999$.

Corbett, J. J., Nicks, D. K., Holloway, J. S., Ryerson, T. B., Neuman, J. A., Nowak, J. B., Brock, C. A., Trainer, M., Hübler, G., Parrish, D. D., Perkins, K. K., Dunlea, E., Sueper, D. T., and Fehsenfeld, F. C.: Measurements of marine vessel emissions and resulting plume chemistry off of the California coast during ITCT 2002, Eos Trans. AGU, 83, Abstract A62B-0160, 2002.

Crutzen, P. J. and Schmailzl, U.: Chemical budgets of the stratosphere, Planet. Space. Sci., 31, 1009-1032, 1983.

Curtis, A. R. and Sweetenham, W. P.: Facsimile/chekmat user's manual, Tech. rep., Computer Science and Systems Division, Harwell Lab., Oxfordshire, Great Britain, 1987.

Davis, D. D., Grodzinsky, G., Kasibhatla, P., Crawford, J., Chen, G., Liu, S., Bandy, A., Thornton, D., Guan, H., and Sandholm, $\mathrm{S}$.: Impact of ship emissions on marine boundary layer $\mathrm{NO}_{\mathrm{x}}$ and $\mathrm{SO}_{2}$ distributions over the Pacific basin, Geophys. Res. Lett., 28, 235-238, 2001.

DeMore, W. B., Sander, S. P., Golden, D. M., Hampson, R. F., Kurylo, M. J., Howard, C. J., Ravishankara, A. R., Kolb, C. E., and Molina, M. J.: Chemical kinetics and photochemical data for use in stratospheric modeling, Tech. Rep. JPL Publication 97-4, Jet Propulsion Laboratory, Pasadena, CA, 1997.

Dentener, F. : Interactive comment on "Modeling the chemical effects of emissions of ships in the marine boundary layer", Atmos. Chem. Phys. Discuss., 2, S176-S179, 2002.

Disselkamp, R. S., Carpenter, M. A., Cowin, J. P., Berkowitz, C. M., Chapman, E. G., Zaveri, R. A., and Laulainen, N. S.: Ozone loss in soot aerosols, J. Geophys. Res., 105, 9767-9771, 2000.
Durkee, P. A., Chartier, R. E., Brown, A., Trehubenko, E. J., Rogerson, S. D., Skupniewicz, C., Nielsen, K. E., Platnick, S., and King, M. D.: Composite ship track characteristics, J. Atmos. Sci., 57, 2542-2553, 2000a.

Durkee, P. A., Noone, K. J., and Bluth, R. T.: The Monterey area ship track experiment, J. Atmos. Sci., 57, 2523-2541, 2000b.

England, C. and Corcoran, W. H.: Kinetics and mechanisms of the gas-phase reaction of water vapor and nitrogen dioxide, Ind. Eng. Chem. Fundam., 13, 373, 1974.

EPA: Compilation of air pollutant emission factors, Tech. rep., United States Environmental Protection Agency, 1972.

EPA: Analysis of commercial marine vessels emissions and fuel consumption data, Tech. Rep. EPA420-R-00-002, United States Environmental Protection Agency, 2000.

Ferek, R. J., Hegg, D. A., Hobbs, P. V., Durkee, P., and Nielson, K.: Measurement of ship-induced tracks in clouds off the Washington coast, J. Geophys. Res., 103, 23 199-23 206, 1998.

Fickert, S., Adams, J. W., and Crowley, J. N.: Activation of $\mathrm{Br}_{2}$ and $\mathrm{BrCl}$ via uptake of $\mathrm{HOBr}$ onto aqueous salt solutions, J. Geophys. Res., 104, 23 719-23 727, 1999.

Finlayson-Pitts, B. J. and Hemminger, J. C.; Physical chemistry of airborne sea salt particles and their components, J. Phys. Chem. A, 104, 11 463-11 477, 2000.

Frick, G. M. and Hoppel, W. A., Airship measurements of ship's exhaust plumes and their effect on marine boundary layer clouds, J. Atmos. Sci., 57, 2625-2648, 2000.

Gerecke, A., Thielmann, A., Gutzwiller, L., and Rossi, M. J.: The chemical kinetics of HONO formation resulting from heterogeneous interaction of $\mathrm{NO}_{2}$ with flame soot, Geophys. Res. Lett. 25, 2453-2456, 1998.

Hobbs, P. V., Garrett, T. J., Ferek, R. J., Strader, S. R., Hegg, D. A., Frick, G. M., Hoppel, W. A., Gasparovic, R. F., Russell, L. M., Johnson, D. W., O'Dowd, C., Durkee, P. A., Nielsen, K. E., and Innis, G.: Emissions from ships with respect to their effects on cloud, J. Atmos. Sci., 57, 2570-2590, 2000.

Kalberer, M., Tabor, K., Ammann, M., Parrat, Y., Weingartner, E., Piguet, D., Rössler, E., Jost, D. T., Türler, A., Gäggeler, H. W., and Baltensperger, U.: Heterogeneous chemical processing of ${ }^{13} \mathrm{NO}_{2}$ by monodisperse carbon aerosols at very low concentrations, J. Phys. Chem., 100, 15 487-15 493, 1996.

Kamm, S., Möhler, O., Naumann, K.-H., Saathoff, H., and Schurath, U.: The heterogeneous reaction of ozone with soot aerosol, Atmos. Environ., 33, 4651-4661, 1999.

Kärcher, B.: Aviation-produced aerosol and contrails, Surv. Geophys., 20, 113-167, 1999.

Kasibhatla, P., Levy, H., Moxim, W. J., Pandis, S. N., Corbett, J. J., Peterson, M. C., Honrath, R. E., Frost, G. J., Parrish, D. D., and Ryerson, T. B., Do emissions from ships have a significant impact on concentrations of nitrogen oxides in the marine boundary layer ?, Geophys. Res. Lett., 27, 2229-2232, 2000.

Kirchner, U., Scheer, V., and Vogt, R.: FTIR spectroscopic investigation of the mechanism and kinetics of the heterogeneous reactions of $\mathrm{NO}_{2}$ and $\mathrm{HNO}_{3}$ with soot, J. Phys. Chem. A, 104, 8908-8915, 2000.

Lawrence, M. G. and Crutzen, P. J.: Influence of $\mathrm{NO}_{\mathrm{x}}$ emissions from ships on tropospheric photochemistry and climate, Nature, 402, 167-170, 1999.

Longfellow, C. A., Ravishankara, A. R., and Hanson, D. R.: Reactive uptake on hydrocarbon soot: Focus on $\mathrm{NO}_{2}$, J. Geophys. 
Res., 104, 13 833-13 840, 1999.

Longfellow, C. A., Ravishankara, A. R., and Hanson, D. R.: Reactive and nonreactive uptake on hydrocarbon soot: $\mathrm{HNO}_{3}, \mathrm{O}_{3}$, and $\mathrm{N}_{2} \mathrm{O}_{5}$, J. Geophys. Res., 105, 24 345-24 350, 2000.

Massin, J.-M. and Herz, O.: La pollution atmosphérique induite par la navigation maritime, Sci. Tot. Env., 134, 343-351, 1993.

Osborne, S. R., Johnson, D. W., Bower, K. N., and Wood, R.: Modification of the aerosol size distribution within exhaust plumes produced by diesel-powered ships, J. Geophys. Res., 106, 98279842, 2001.

Rogaski, C. A., Golden, D. M., and Williams, L. R.: Reactive uptake and hydration experiments on amorphous carbon treated with $\mathrm{NO}_{2}, \mathrm{SO}_{2}, \mathrm{O}_{3}, \mathrm{HNO}_{3}$, and $\mathrm{H}_{2} \mathrm{SO}_{4}$, Geophys. Res. Lett., 24, 381-384, 1997.

Saathoff, H., Naumann, K.-H., Riemer, N., Kamm, S., Möhler, O., Schurath, U., Vogel, H., and Vogel, B.: The loss of $\mathrm{NO}_{2}, \mathrm{HNO}_{3}$, $\mathrm{NO}_{3} / \mathrm{N}_{2} \mathrm{O}_{5}$ and $\mathrm{HO}_{2} / \mathrm{HOONO}_{2}$ on soot aerosol: A chamber and modeling study, Geophys. Res. Lett., 28, 1957-1960, 2001.

Sander, R.: Modeling atmospheric chemistry: Interactions between gas-phase species and liquid cloud/aerosol particles, Surv. Geophys., 20, 1-31, 1999.

Sander, R. and Crutzen, P. J.: Model study indicating halogen activation and ozone destruction in polluted air masses transported to the sea, J. Geophys. Res., 101, 9121-9138, 1996.

Sander, R., Rudich, Y., von Glasow, R., and Crutzen, P. J.: The role of $\mathrm{BrNO}_{3}$ in marine tropospheric chemistry: A model study, Geophys. Res. Lett., 26, 2857-2860, 1999.

Sander, S. P., Friedl, R. R., DeMore, W. B., Golden, D. M., Kurylo, M. J., Hampson, R. F., Huie, R. E., Moortgat, G. K., Ravishankara, A. R., Kolb, C. E., and Molina, M. J.: Chemical kinetics and photochemical data for use in stratospheric modeling, Tech. Rep. JPL Publication 00-3, Jet Propulsion Laboratory, Pasadena,
CA, 2000.

Seinfeld, J. H. and Pandis, S. N.: Atmospheric Chemistry and Physics, John Wiley \& Sons, New York, Chichester, Weinheim, 1998.

Song, C. H., Chen, G., Hanna, S. H., Crawford, J., and Davis, D. D.: Dispersion and chemical evolution of ship plumes in the marine boundary layer: Investigation of $\mathrm{O}_{3} / \mathrm{NO}_{\mathrm{y}} / \mathrm{HO}_{\mathrm{x}}$ chemistry, submitted to JGR, 2002.

Streets, D. G., Carmichael, G. R., and Arndt, R. L.: Sulfur dioxide emissions and sulfur deposition from internatinal shipping in Asian waters, Atmos. Environ., 31, 1573-1582, 1997.

Streets, D. G., Guttikunda, S. K., and Carmichael, G. R.: The growing contribution of sulfur emissions from ships in Asian waters, 1988-1995, Atmos. Environ., 34, 4425-4439, 2000.

Vogt, R., Crutzen, P. J., and Sander, R.: A mechanism for halogen release from sea-salt aerosol in the remote marine boundary layer, Nature, 383, 327-330, 1996.

von Glasow, R.: Modeling the gas and aqueous phase chemistry of the marine boundary layer, Ph.D. thesis, Universität Mainz, Germany, http://www.rolandvonglasow.de, 2000.

von Glasow, R., Lawrence, M. G., Sander, R., and Crutzen, P. J.: Modeling the chemical effects of emissions of ships in the marine boundary layer, Atmos. Chem. Phys. Discuss., 2, 525-575, 2002a.

von Glasow, R., Sander, R., Bott, A., and Crutzen, P. J.: Modeling halogen chemistry in the marine boundary layer. 2. interactions with sulfur and cloud-covered MBL, J. Geophys. Res., 107, 4323, doi: 10.1029/2001JD000 943, 2002b.

von Glasow, R., Sander, R., Bott, A., and Crutzen, P. J.: Modeling halogen chemistry in the marine boundary layer. 1. cloud-free MBL, J. Geophys. Res., 107, 4341, doi: 10.1029/2001JD000 942, 2002c. 